Öz

Birçok farklı yaklaşımla yerleşme tarihi alanında üretilen çalışmalarda yöntem, seçilen örnek alan, tarihsel analizin yapıldığı zaman aralığı, çalışmaya kaynak oluşturan yazılı ve görsel materyaller gibi pek çok değişken; çalıșmanın sonuç ürününü etkilemektedir. Şehircilik çalışmaları açısından yerleşmenin bir tarihsel kesitte makroform gelişimi ve kentsel biçimlenmesinin araştırılması kadar, biçimlenmeyi etkileyen dinamiklerin ilişkisel olarak ele alınması da önem taşımaktadır. Yerleşme tarihi analizini ölçeklerarası, zamanlararası ve temalar arası bir bakış açısıyla yapmayı hedefleyen bu çalışma, bu bağlamda tarihsel coğrafya ve kentsel morfoloji disiplinleri perspektifinde bir çerçeve sunmaktadır. Burada amaç, yerleşme tarihi analizinde kullanılan tarihsel metinler ile görsel dokümanlar arasında bir ilişki kurarak, yerleşme tarihi analizinde bu iki veri alanını birleştirmektir. Bu ilișkinin kurulabilmesi için geliştirilen yaklaşımda, iki bileșen tanımlanmıștır. Yerleşme tarihi analizinin iki bileşeninin ilkini yazılı kaynaklar temelinde görsel malzemenin işlenmesiyle oluşturulan yerleşme tarihi analizi tablosu oluştururken, diğer bileşen -aynı zamanda yerlessme tarihi analizi tablosunun bir katmanını oluşturan- tarihsel/ güncel harita analizi olarak belirlenmiştir. Tarihsel haritaların ișlenmesi, yerleșme tarihinin mekânsal gelişimi ile yerleşmeye etki eden diğer toplumsal etkenlerin karşlıklı ilişki içinde ele alınmasını kolaylaştırmaktadır. Çalışmanın ana referansını oluşturan Doktora Tezinde (Tezer, 2019) "Kentsel morfoloji ve tarihsel coğrafya ışığında sistematik bir yerleşme tarihi analizi çerçevesi geliştirmek mümkün müdür?" şeklinde kurgulanan araştırma sorusuna cevap arayan bir yöntem tartışması, bu makalenin ana konusunu oluşturmaktadır. Abstract

In the studies produced in the field of settlement history with many different approaches, many variables such as method, selected sample area, time interval during historical analysis, written and visual materials that constitute the source of the study; affects the result of the study. In terms of urban studies, it is important to examine the dynamics affecting the formation in a relational way as well as the research of change of macroform and urban formation of the settlement in a historical section. This study, which aims to make the analysis of settlement history with an inter-scale, intertemporal and inter-themes perspective, provides a framework in the context of historical geography and urban morphology disciplines in this context. The aim is to combine these two data fields in settlement history analysis through establishing a relationship between historical texts and visual documents used in settlement history analysis. In the approach developed to establish this relationship, two components are defined. While the first one of the two parts of the settlement history analysis constitutes the settlement history analysis table created by processing the visual

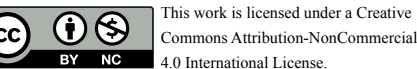

\title{
Yerleşme Tarihi Analizi Için Yöntemsel Bir Çerçeve Önerisi: Kentsel Morfoloji ve Tarihsel Coğrafyanın sunduğu Olanaklar
}

D Saadet Tuğçe Tezer Mimar Sinan Güzel Sanatlar Üniversitesi Mimarlık Fakültesi, Şehir ve Bölge Planlama Bölümü

Başvuru tarihi/Received: 12.06.2020, Kabul tarihi/Final Acceptance: 20.01 .2021

\section{Giriş}

Yerleşme tarihi çalışmalarında bugüne kadar yazılı ve görsel verilerin farklı düzeylerde analizlerine dayalı çok farklı yaklaşımlar geliştirilmiştir. Bu çalışmalarda yöntem, örnek yerleşme, zaman aralığı, yazılı ve görsel veriler gibi değişkenler, çalışma sonucunu etkilemektedir. Bir bölümü yazılı ve sayısal verilerin değerlendirilmesine, bazıları ise mekânsal gelişme katmanlarına odaklanan çalışmaların pek çoğunda mekânsal ve yazılı-sayısal veriler ilişkisel olarak ele alınmamaktadır. Kentlerin tarihsel gelişim süreçlerini katmanlar arası ilişkisellikleri de gözetecek şekilde kavramaya engel olan bu durumun karşısında; yerleşme tarihi analizini ölçeklerarası, zamanlararası ve temalar arası bir bakış açısıyla yapmayı hedefleyen bu çalışma, tarihsel coğrafya ve kentsel morfoloji disiplinleri perspektifinde bir çerçeve sunmaktadır. Burada amaç, yerleşme tarihi analizinde kullanılan tarihsel metinler ile görsel dokümanlar arasında bir ilişki kurmak, yerleşme tarihi analizi için bu iki veri alanını birleştirmektir. Bu ilişkinin kurulabilmesi için geliştirilen yaklaşımda, iki bileşen tanımlanmıştır. İlk bileşeni yazılı kaynakların görsel malzemeyle beraber işlenmesiyle oluşturulan yerleşme tarihi analizi tablosu oluştururken, diğer bileşen -aynı zamanda yerleşme tarihi analizi tablosunun bir katmanını oluşturanharita analizi olarak belirlenmiştir. Tarihsel haritaların işlenmesi, yerleşmenin tarihsel süreçte mekânsal gelişimi ile yerleşmeye etki eden diğer toplumsal etkenlerin ilişkili olarak ele alınmasını kolaylaştırmaktadır.

Bu makalenin konusunu "Kentsel morfoloji ve tarihsel coğrafya ışığında sistematik bir yerleşme tarihi analizi çerçevesi geliştirmek mümkün müdür?’’ araştırma sorusuna cevap arayan bir yöntem tartışması oluşturmaktadır. Çalışmada kentin üst ölçekli bölgeselliği ile alt ölçekli mekânsal bileşenlerini biraraya getirmek, bu ölçekler arasındaki etkileşimi ve bunun üzerinden yerleşmelerin tarihsel geçmişini ortaya çıkarmak hedeflenmektedir. Bu çerçevede bu makalede bir yöntem tartışması yapılmakta, önerilen yöntemsel çerçeve gerekçeleri, adımları ve imkanlarıyla açıklanmaktadır. Çalışma aynı zamanda bu tarihsel ele alışa ilişkin bir çerçeveyi tüm yerleşmeler için kullanmanın imkânını ve araçlarını tartışmaya açmayı amaçlamaktadır.

Bu kapsamda makale dört ana kısımdan oluşmaktadır. Öncelikle mevcut yerleşme tarihi çalışmalarına dair hangi hususların yeniden sorgulanmasının gerekli olduğu, bu alanda yapılan çalışmaların geçmişi üzerinden ele alınmıştır. Ardından yerleşmelerde gerçekleşen mekânsal değişimi anlamada metodolojik bir yöntem sunan 
material on the basis of written sources, the other part is determined as historical/current map analysis which also constitues a layer of the settlement history analysis table. Processing of historical maps facilitates the interaction of the spatial development of the settlement history and other social factors affecting the settlement. The main topic of this article is to answer this research question -which comes from main reference of this paper; PhD thesis (Tezer, 2019)- with a method discussion: "Is it possible to develop a systematic framework for settlement history analysis in the light of urban morphology and historical geography?"

Anahtar Kelimeler: Yerleșme tarihi, yerleșme tarihi analizi, tarihsel coğrafya, kentsel morfoloji.

Keywords: Settlement history, settlement history analysis, historical geography, urban morphology. kentsel morfoloji alanı incelenmiştir. Kentsel morfoloji yöntemleri daha çok kentin (fiziksel) biçimlenmesine odaklandığından, yerleşmelerin biçimlenmesindeki toplumsal, iktisadi, kültürel ve siyasi etkenleri anlayabilmek için morfolojik yaklaşımları destekleyecek bir metodolojik kavram setine gereksinim doğmuştur. Bu eksiklik, belirtilen kavramlara dair metodolojik bir bakış açısı olanağı taşıyan tarihsel coğrafya yaklaşımının çalışmaya dahil edilmesiyle giderilmiştir. Bu kapsamda kentsel morfoloji ve tarihsel coğrafya yöntemleri incelenerek, bu disiplinlerin yerleşme tarih açısından sunduğu olanaklar değerlendirilmiştir. Ardından yerleşme tarihi analizi için yöntemsel bir çerçeve önerisi sunularak imkân ve kısıtlılıkları bağlamında işlenmiş, metin sonuç bölümüyle tamamlanmıştır.

\section{Yerleşme Tarihi Analizinde Mevcut Yaklaşımların Değerlendirilmesi}

Yerleşme tarihine getirilen farklı yaklaşımlarda, mekânsal ve yazılı-sayısal verilerin birbiriyle ilişkilerinin kurulmaması, yerleşmenin tarihsel gelişiminin yeterince anlaşılmasının önünde bir engel teşkil etmektedir. Önerilen yöntemsel çerçeve ile yerleşmeyi coğrafi, fiziksel, sosyal, ekonomik, kültürel, tarihsel katmanları dahil ederek incelemenin olanaklarını araştırmak, kapsamlı ve anlaşılır bir yerleşme tarihi analizi gerçekleştirmek hedeflenmiştir. $\mathrm{Bu}$ kısımda mevcut yerleşme tarihi çalışmalarının geçmişi incelenerek, yeniden değerlendirilmesi gerektiği düşünülen hususlar araştırılmaktadır.

Yerleşme tarihi çalışmalarına ilişkin yaygın bir düşünce, akademik açıdan bir araştırma metodolojisine oturtulamamış ve bağımsız bir disiplin alanı oluşturmaması olsa da, ülkemizde pek çok yerleşme tarihi çalışması örneği bulunmaktadır. Farklı disiplinlerden araştırmacıların yaptığı yerleşme tarihi çalışmalarına diğer disiplinlerin çalışma konularının dahil edilmemesi, yerleşme bütününün algılanamamasına neden olmaktadır (Göncüoğlu, 2011). Tüm dünyada yerleşme tarihi çalışmaları arkeoloji, mimarlık ve sanat tarihi çalışmalarına temellenmekte, araştırmalarda kent formundan kentsel mekâna doğru bir biçimsel dönüşüm arayı- ş1 görülmektedir. Kentleri mekânsal açıdan inceleyen araştırmalar 19. yüzyıldan sonra kentsel coğrafya, kentsel biçimlenme ve makroforma odaklanırken; kent monografileri ve kentsel morfoloji çalışmaları da üretilmiştir. İlerleyen dönemde bu çalışmalara kentsel ve kamusal mekanların biçimlenmesine odaklanan çalışmalar eklenmiştir. $\mathrm{Bu}$ çalışma deneyimleri ilerleyen dönemde coğrafi mekân ve toplumsal, ekonomik, kültürel süreçleri birlikte inceleyen tarihsel araştırma yaklaşımının temellerini oluşturmuştur (Bilsel, 2015). 19. yüzyılın sonları, Türkiye'de kentin tarihinin yazılabilecek bir toplumsal olgu ya da özne olarak görüldüğü, yerelin tarihinin yazılması çalışmalarının başladığı dönemdir. Yerel tarih araştırmalarına duyulan ilginin sebepleri; yabancıların çalışmalarının etkisi, 1870'li yıllarda kurulan vilâyet matbaaları, vilâyet salnâmelerinin yayımlanması, belediyelerin kurulmaya başlamasıdır (Tekeli, 2010). 20. yüzyıldan itibaren bu alandaki çalışmalar kent planları, kent meydanları, kentlerin evrimi, "kent belleği”, "kentsel olgu" kavramlarına odaklanmıştır. Kentsel biçimlenmeye dair çalışmalar önemini korurken, mimarlık tarihini toplumsal süreçler ve kentlerin fiziksel bağlamıyla ilişkilendiren çalışmalar üretilmiştir (Bilsel, 2015). Bu dönemde seyyahların artması ve kent rehberlerine gereksinim duyulmaya başlanması, Türkiye'de yerleşme tarihi çalışmalarını artıran sebeplerdendir. 1870'lerden itibaren artış gösteren yerel tarih çalışmalarında 2000'den sonra nitelik ve nicelik açısından önemli bir gelişme ve çeşitlenme görülmektedir (Tekeli, 2010).

Yerleşmenin tarihsel özelliklerinin açığa çıkarılmasının, ancak incelenen yerleşmenin oluşumunu belirleyen sosyo-mekânsal süreçlerin, kentin mekânsal çerçevesinin değiştiğii, dönüştüğü sıçrama/kırılma noktalarına temellenmiş bir tarihsel çerçeve üzerinden kurulabileceğini belirtmek mümkündür. Farklı disiplinlerden araştırmacıların farklı yaklaşımlarla yaptığ 1 yerleşme tarihi çalışmalarının çoğulcu yapısını sürdürmesi ve bu araştırma alanında karş1lıklı etkileşime imkân sağlayan akademik tartışmaların üretilmesi; çalışmaların niteliğinin gelişmesini sağlayacaktır (Tekeli, 2010). zumanda, çalısmanin ana referansını olusturan Doktora Tezinin de temel araștirma sorusudur (Tezer, 2019). 
Son yıllarda haritalama teknolojisindeki gelişmeler, kentsel mekâna dair araştırmaları daha çeşitli hale getirmiş ve sosyal bilimler alanındaki çalışmaların bir kısmı -bu sayede- çokdisiplinli çalışma alanlarına dönüşmeye; farklı nitelik ve yaklaşımdaki çalışma grupları arasındaki sınırlar belirsizleşmeye başlamıştır.

\section{Yerleşme Tarihi Analizinde Kentsel Morfoloji ve Tarihsel Coğrafya}

\subsection{Kentsel Morfoloji Yöntemi}

Kentsel morfoloji yönteminin gelişim sürecini, konuya farklı yaklaşımlar ve yöntem bileşenleri çerçevesinde incelemek mümkündür. Kentsel morfoloji çalışmalarında, kuruluşları itibariyle mesleki kökenler (mimarlık ve coğrafya kökenli yaklaşımlar) ve farklı yöntemsel yaklaşımların geliştiği ülkelere (İngiliz, İtalyan ve Fransiz ekolü) göre iki tür ayrım söz konusudur. İtalyan ve Fransız ekolleri daha çok mimarlık kökenli yaklaşımlarla örtüşürken, İngiliz ekolü büyük ölçüde coğrafya kökenli yaklaşımı oluşturmaktadır. Günümüzde bu yaklaşımlar farklı yöntem ve araçlar geliştirse de temel olarak İtalyan, Fransız ve İngiliz ekolleri kentsel morfoloji çalışmalarında belirleyicidir.

Moudon'a göre kentsel morfoloji disiplininin geldiği nokta itibariyle, erişebileceği alanlara dair iki temel olanak söz konusudur. Öncelikle kentsel morfoloji çalışmalarının küçük ölçekte doku incelemesi yapan ve bu şekilde tasarım çalışmalarına yol gösteren niteliği, gelişen teknolojik imkânlar sayesinde artık geniş alanlar üzerinde de ayrıntılı incelemeler yapmaya olanak sağlamaktadır. Önceden geniş alanları ancak makro değişiklikler üzerinden incelemeye imkân veren teknikler, teknolojik gelişmelerle sayesinde "makro ölçekte mikro incelemeler" yapmaya olanak sağlar hâle gelmiştir. Dolayısıyla artık kent ve çevresine ilişkin detaylı incelemeler yapmak mümkündür. Diğer olanak ise, yine gelişen teknolojiyle beraber kentsel morfolojinin farklı tematik eksenlerin sentetik analizine, çeşitli tematik verilerin birlikte okunmasına olanak sağlamasıdır (Moudon, 1994). Bu öngörünün günümüzde büyük ölçüde gerçekleştiğini, kentsel morfoloji alanında yapılan çalışmalarda teknolojinin olanaklarının etkin kullanıldığı detaylı ve karşılaştırmalı analizlerin yer aldığı çalışmaların yapıldığını belirtmek mümkündür.

\subsubsection{Kentsel Morfolojide Coğrafya ve Mimarlık Kökenli Yaklaşımlar}

Kentsel morfolojide coğrafya kökenli yaklaşımlar Almanya'da, Schlüter' in (1899) çalışmalarıyla başlamış; yerleşim planı, kent coğrafyası ve Alman kentleri üzerine yaptığ1 monografik çalışmalarla gelişmiştir. Yerleşim yoğunlukları üzerinde arazi kullanımı ve bina kullanımlarına ilişkin çalışmaların (Hassinger, 1916) ardından monografik sınıflandırmaya dayalı şehir planı ve yapı tipleri (Geisler ve Martiny, 1924-1928), kentlerin zaman içinde gösterdiği işlevsel değişime (Bobek, 1966) dair çalışmalar gerçekleştirmiştir. M.R.G. Conzen' in (1959) tarihsel bakış, coğrafya ve kentsel morfoloji üzerine yaptığ çalışmalardan sonra Whitehand'in (1981) kentsel morfolojiye ilişkin kavramsal önerileriyle; kentsel morfoloji disiplininde coğrafya temelli bakış büyük ölçüde bugünkü durumuna erişmiştir. Kent tarihi, kent planlama tarihi, kent formu ve belirleyicileri, kadastral planlar üzerinden kent planlarının oluşumuna dair çalışmaların ardından kentsel morfoloji çalışmalarının odağı, formdan fonksiyona dönüşmüştür (Whitehand, 1987, 3-7).

Conzen çalışmalarında sokak, sokak sistemi, ada ve parseller üzerinden kent planını incelemiş ve Conzen ilkelerini oluşturmuş; Whitehand'in sürdürdüğ̈ ve savaş sonrası kentlerin geçirdiği dönemlere odaklanan çalışmalar, coğrafya temelli çalışmalar arasında önemli bir yer tutmuştur. Büyük ölçüde M.R.G. Conzen'in tanımladığı ve geliştirdiği coğrafya temelli kentsel morfoloji yaklaşımı; Kropf (2009), Whitehand (1988), M.P. Conzen (2009), Maretto (2013), Kim (2012), Gu (2010) gibi araştırmacıların çalışmalarıyla gelişmeyi sürdürmüş, fakat yaklaşımın temelinde bir değişiklik olmamiştır (Cömert, 2013, 18-19).

Kentsel morfolojide mimarlık kökenli yaklaşımlar Vitruvius'un kullanışlılık, sağlamlık ve güzellik üçlemesine temellenmektedir; bu tipolojik sınıflandırma aynı 
zamanda işlevleri de içermektedir (Pevsner, 1976). İşleve dayalı sınıflandırmayı (Blondel, 1777), katı bir tipoloji anlayışı yerine zamana dayalı değişim ve dönüşümlere odaklanan, işlevin mimari tipi oluşturması gerektiğini öne süren çalışmalar izlemiştir (Forty, 2000). Genellikle tipoloji çalışmalarına odaklanan mimarlık kökenli yaklaşımda Muratori (1959), Cataldi (2003), Petruccioli (1998), Caniggia ve Maffei (2001), Moudon (1997), Rossi (1982), Krier (1979) ve Hillier (1998) önemli çalışmalar üretmiştir (Cömert, 2013, 20-26). Tipomorfolojiyi "tarihi tipolojik araştırmalar ve tasarım gelişimi aşamalarında tamamlayıcı ve dönüşümlü zamanlar arasındaki diyalektik ilişki” olarak tanımlayan Muratori; yapı bileşenlerinin okunması, biçim, yapıların fonksiyonları, kentsel ve yapısal dokuların oluşmasına ilişkin kuralların ortaya konulması üzerine çalışmıştır (Petruccioli, 1998, 10; Caniggia\&Maffei, 2001, 10-21). Muratori'den sonra Caniggia, tiplerin evrimi ve tipleri oluşturan bileşenler üzerinden "tipolojik süreç" olarak tanımladığı kentsel form değişkenleri üzerine çalışmış, tiplerin ve kentsel dokuların tarihsel süreçte oluşumu ve dönüşümüne odaklanmıştır (Levy, 1997, 52). Caniggia teorisini yapılar, yapı dokusu, yerleşmeler ve kentler (kırsal yerleşmelerin kentlere, basit kentlerin karmaşık kentlere dönüşümü) şeklinde kavramsallaşmıştır. (Caniggia\& Maffei, 18-21). Argan'ın biçimsel tipoloji ve morfolojik hafızaya dair çalışmaları "tip"in oluşumuna ve tasarım süreçlerinde kullanılmasına odaklanırken, yeni tiplerin oluşmasını teknolojik ve sosyo-kültürel dinamiklerle ilişkilendirmesi açısından önemlidir (Argan, 1962, 2; Cömert, 2013, 23). Her ikisi de geçmişin nostaljik görünümünü bir belirleyici olarak kabul eden Rossi (1982) tipolojiyi kentsel olguların incelenmesinin bir aracı olarak tanımlarken, Krier (1979), kentsel mekân kavramının tipolojik ve morfolojik bileşenlerini ele almaktadır (Marzot, 2002, 66).

Kentsel morfolojide mimarlık kökenli yaklaşımlarda Hillier'in (1998) önerdiği "mekân dizimi” (space syntax) çalışmaları; mekâna dair çalışmaları kuramsal anlama süreçleriyle birleştirmekte, dokuya ilişkin biçimsel tanımlar ile istatistiki verilerin bağlantısını kurarak, deneysel gözlemleri bilgisayar desteğiyle ilişkilendirmiştir (Hillier\&Hanson, 1998, 108). Amerikan kentleri üzerine önemli tipo-morfoloji çalışmaları bulunan Moudon ise kentsel morfolojinin üç temel bileşeni (biçim, ayrışma ve zaman) üzerinden hareket etmiş; ideolojik, kültürel ve ekonomik açıdan zaman ve kentlere göre farklılaşan form çeşitlilikleri üzerine çalışmıştır (Moudon, 1997).

\subsubsection{Kentsel Morfolojide İngiliz, Italyan ve Fransiz Ekolleri}

İngiliz kentsel morfoloji ekolü Conzen'in çalışmalarına temellenmekte, Conzen'in kentsel morfoloji analizi yöntemi üç kategoriye dayanmaktadır: Kent planı, bina dokusu ve arazi kullanımı (Whitehand, 2007, 3). Kentsel morfolojide tarihsel-coğrafi yaklaşımın kurucusu olan Conzen'e göre kent, farklı düzeylerinde (alt, orta, üst ölçekte) üretilen kentsel örüntülerin birbirinin içine geçip bütünleşmesi ile oluşmaktadır. Yöntemin temellendiği üç bileşenin biraraya gelerek oluşturduğu karmaşık düzen, kent içinde birbirine benzeyen morfolojik birimleri oluşturmaktadır. Alt, orta ve üst ölçeklerde biraraya gelen üç bileşenin ürettiği morfolojik bölgelerin birbirine bağlı bir şekilde kenti üretmesi, "morfolojik bölgelerin kademeli olarak içiçe geçmesi" olarak tanımlanmaktadır (Ünlü, 2019, 63). Her örüntünün üstündeki ve altındaki diğer birer örüntüye bağlı olması; yani alt ölçekte üretilen örüntünün üst ölçekten gelen bütünlüğün, üst ölçekten gelen örüntünün ise alt ölçekten gelen örüntünün parçası olması gerekliliği, kentte bir örüntü dilinin kurulmasına olanak sağlar (Alexander\& Silverstein, 1977; Ünlü, 2019, 63-64).

Conzen' in “kent-planı analizi” yöntemi, kent planının üç temel bileşenini esas almaktadır: Sokaklar, parseller, binalar. Kent planının evrimsel bir şekilde analiz edilebileceğini öne süren Conzen'in kent planının bileşenlerini analitik bir araç olarak tanımlaması, tipomorfolojik çalışmanın çıkış noktasıdır. Analizin temel birimi olan parseller (mülkiyet deseni), aynı zamanda arazi bölümlenmesinin temel öğesidir (Moudon, 1994, 296-298). Kent formunu anlamak için, (sürekliliği olan) ulaşım ve fiziksel mekân bile- 
şenlerinin tarihsel süreçleriyle incelenmesi, iyi bir araçtır (Moudon, 1997, 7-8). Conzen'in kentsel morfoloji yönteminin temel bileşenleri arasında en az dirençli/dayanıklı olan öğeler binalar ve kullanımlar olup, değişkenlik gösterme eğilimleri yüksektir. En kalıcı unsuru oluşturan sokak sistemi ve parsel dokusunun bu niteliği ise, arka planındaki mülkiyet ilișkilerinden kaynaklanmaktadır (Bas, 2010, 30). Conzen' in kentsel morfoloji çalışmalarına temel katkısı, tarihsel-coğrafi bakış açısı ve yerleşme formlarına dair çalışmaları olup, Conzen metodu kendisinden önceki Alman coğrafyacılardan ayrışarak kendi ismiyle anılmış; giderek İngiliz ekolünü oluşturmuştur (Cömert, 2013, 17).

Conzen'in tarihsel süreçte kentlerin oluşumu ve gelişimini sistematik bir coğrafi yaklaşımla incelediği Alnwick (1959-1960) çalışması; yer, işlev, kentsel peyzaj (townscape), sosyal ve ekonomik bağlam, gelişme olarak belirlenen beş temel unsur ortaya koymaktadır. Kentsel peyzaj ise kent planı, arazi kullanım ve bina dokusu bileşenlerinden oluşmaktadır (M.R.G. Conzen, 1959). Yöntemin (ve kent planinin) üç temel bileşeni olan sokak, parsel ve bina deseniyle oluşan plan üniteleri farklı biçimlerde biraraya gelmekte, alt üniteler oluşturmaktadir (Kropf, 2009).

Conzen'in kentsel morfoloji literatürüne katkısı olan "parsel döngüsü"² ve "kentsel çeper kuşak"3 kavramları, bu alanda yapılan güncel çalışmaların çoğunda araştırma yöntemini olușturmaktadır. Kentsel morfolojinin İngiliz ekolünün kurucusu olan ve günümüzde yapılan çalıșmaların büyük bir kısmında yöntemsel yaklaşımı kullanılan Conzen'in (1959) Alnwick çalışmasında "üst ölçek" kavramı, kentin makroformuna karșılık gelecek biçimde kullanılmaktadır. Conzen yapı-parsel-sokak düzeyinde yapılan detaylı morfolojik inceleme çalışmasının üst çatısını kentin yerleşme lekesinin yayılım gösterdiği ve makroformunun sınırını belirleyen alan üzerinden kurmaktadir. (M.R.G. Conzen, 1960).

Kentsel morfolojide tarihsel coğrafi yaklaşımın temellerini yukarıda belirtildiği gibi Conzen 1960 yılında yaptığ 1 Alnwick çalışmasıyla atmıştır. 1970'lerin sonunda

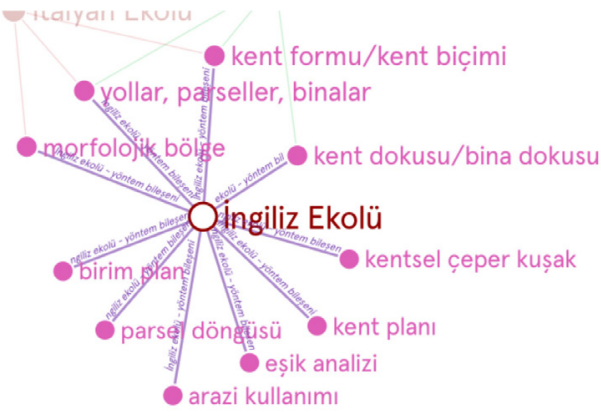

Whitehand'in kentsel formu tarihsel-coğrafi yönleri yerine sosyal ve ekonomik süreçler üzerinden açıklamaya dayanan çalışmaları ile çalışmalar farklı bir alanda ilerlemeye başlamıştır (Whitehand, J, 1977; Oliveira, V., 2019: 10-11). Ardından 1981'de Whitehand'in "kentsel peyzaj" çalışmas1nın merkezine Conzen'in tarihsel coğrafi yaklaşımını yerleștirdiği ve kent planı analizini daha da detaylandırdığ 1 çalışmalar gelmiştir. İlerleyen yıllarda Whitehand'in çalışmalarına ek olarak Larkham (1998) ve Slater'in (1990) çalışmaları da önemli katk1lar sunmuştur (Oliveira, V., 2019: 10-11). 2000'li y1llarda ise Kropf (2009), Oliveira (2015) ve yine Whitehand'in (2014) çalışmalarıyla kentsel morfolojiye tarihsel-coğrafi yaklaşım, tipolojik süreç incelemeleri ve mekânsal analizlerle devam etmektedir (Oliveira, V., 2019: 25).

İngiliz kentsel morfoloji ekolünde yöntemin bileşenleri; yollar, parseller ve binalardan oluşan kent planı, kent dokusu/ bina dokusu, arazi kullanımı, kentsel çeper kuşak, parsel döngüsü, kent formu analizi, birim plan, eşik hattı ve morfolojik bölge olarak tespit edilmektedir (Sekil 1).

Temelini 1900'lerin başından itibaren “tipoloji” incelemeleri yapan Muratori'nin (1959) oluşturduğu İtalyan kentsel morfoloji ekolünün bugünkü biçimini almasında, "tipolojik süreç” yaklaşımını geliştiren Caniggia'nın araştırmaları etkili olmuştur (Caniggia\&Maffei, 2001). Tipolojik süreç yaklaşımında, yapı tiplerinin kentsel biçimin temel unsurunu oluşturduğu düşüncesinden yola çıkılarak, işlevsel ve fiziksel biçimler ile değişimde etkili olan kültürel süreçler incelenmektedir. Yapılı çevrenin tarihsel oluşum sürecini ve yapısının incelendiği çalışmalar; mekânsal ve zamansal korelasyon yöntemleri kul-
Sekil: I

Ingiliz kentsel morfoloji ekolü - Yöntemin

temel bilesenleri (Tezer, 2019).
2 "Parsel döngüsü" (burgage cycle): Bir parselde bulunan bina sayısındaki değissimi parsel içinde inşa edilen ilk yapıya, kentt meydana gelen insaat faaliyetlerindeki artışla beraber yeni yapiların eklenmesi ve sonrasinda çeşitli sebeplerle bu yapiların sayısinda azalma meydana gelmesini ifade eder (Whitehand, 2007, 3-4).

3 "Kentsel seper kusak" (urban fringe belt): Kentteki inşaat faaliyetlerinin az olduğu dönemlerde meydana gelen; yeşil alanlar, spor alanları ve kamu yapilarının yer aldı̆̆ geniş araziler (Whitehand, 2007, 3-4). J.W.R. Whitehand ekonomi, rant teorisi ve konut yapılaşması döngüsünü "kentsel çeper kuşak" gelişimi ile ilişkilendiren bir yaklaşım geliştirmiştir (Slater, 2009, 59-65). Kentsel çeper kuşaklar, kısıtlayıcı etki oluşturan bir "eşik hattı"nın (fixation line) olduğu durumlarda güçlü bir şekilde ortaya çıan, kentin büyümesini sinirlandiran ve genellikle doğrusal nitelik taşıyan alanlardir. Kentin büyümesini yavaşlatan veya durduran bu sinırlayıcı alanlar, doğal veya yapay eşiklerden oluşabilir (M.R.G. conzen, 1960). 
lanılarak, genel bir mekânsal ve zamansal değişkenler ayırımının yapılmasıyla başlamaktadır (Caniggia\&Maffei, 2001). Mekânsal korelasyon analizi; elemanlar, elemanlar strüktürü, strüktürler sistemi ve sistem organizmasını içermektedir. Bu düzenin inşaat malzemeleri ve tekil yapılarla başlayarak komşuluk üniteleri, mahalleler ve kentsel ölçeğe kadar uygulanmasıyla ortaya çıkan farklı dokuların kombinasyonu, araştırma yönteminin diğer bileşenlerini oluşturmaktadır (Caniggia\&Maffei, 2001).

İtalyan kentsel morfoloji ekolünün yöntem bileşenleri; tip/tipoloji, tipo-morfolojik yaklaşım, morfolojik bölge, yapı malzemeleri, binalar ve açık alanları, kent biçim ve yapısı ile sosyal, ekonomik ve kültürel faaliyetlerden oluşmaktadır (Şekil 2).

Fransa'daki kentsel morfoloji çalışmaları 1968 yılından itibaren Versailles Mimarlık Okulu geleneği üzerine gelişmiştir. Geleneklere temellenen mimarlığın kökenlerinin yeniden keşfedilmesi gerektiği düşüncesiyle yola çıkan ve disiplinlerarası bir araştırma alanı tanımlayan Fransız ekolünde "tipomorfolojik" yaklaşım önemlidir. 1970'lerden itibaren bina tipleri ve kent biçimi arasındaki ilişkiye odaklanan çalışmalar, savaş sonrası hasar görmüş ülkenin yeniden inşası konusuna yoğunlaşmıştır. Versailles Mimarlık Okulu'nun çalışmaları Lefebvre'in fikirlerinin çatısı altında, disiplinlerarası çalışmayı benimseyerek sosyal bilimlerle uzlaşmayı ve "sosyal olarak cevap veren sorumlu bir mimarlık anlayışı”nı geliştirmiştir (Moudon, 1994).

Fransız ekolünün yöntem bileşenleri tipomorfolojik yaklaşım, bina tipleri, kent biçimi, konut üretimi, öğelerin tipolojisi, anitsal yapilar, kent formu ve kent dokusundan oluşturmaktadır (Şekil 3).

Coğrafya kökenli ve mimarlık kökenli yaklaşımlar ile İngiliz, İtalyan ve Fransız kentsel morfoloji ekollerinin temsilcilerinin bu alanda yaptıkları önemli çalışmaların tarihleri ile biraraya getirildiği Şekil 4'e göre; kentsel morfolojide coğrafya kökenli yaklaşım büyük ölçüde İngiliz ekolünde kullanılmaktadır. Ağırlıklı olarak coğrafyacıların yürüttüğü bu çalışmalar, yerleşmelerin tarihsel geçmişleri ve üst ölçekleriyle ilişkilenme potansiyeli taşımaktadır. Her üç ekolde de mimarlık kökenli yaklaşımla çalışmalar yapılmakta olup, mimari ölçeğe temellenen bu çalışmalarda ise, üst ölçek olarak kabul edilebilecek kentsel ve bölgesel ilişkiler -tekil örnekler dışında- dahil edilmemiştir.

İngiliz kentsel morfoloji ekolünde kentsel form çalışmaları ve kentsel yapı kuramlarını geliştirmeyi amaçlayan çalışmalar yoğunlaşmakta olup, kentlerin nasıl ve neden inşa edildiği sorusuna cevap arayan coğrafyacıların çalışmalar ürettiği ekolün önemli temsilcileri Conzen ve Whitehand'dir.

Kentsel form çalışmalarının kentsel tasarım teorisini geliştirmek üzere tanımlayıcı bir amaç benimsediği İtalyan ekolü ise, kentlerin nasıl inşa edildiğine odaklanır. Ağırlıklı olarak mimarların çalışmaları üzerinden gelişen İtalyan ekolünün önemli temsilcileri Muratori, Caniggia ve Rossi'dir. Kentsel yapılara ilişkin geçmiş tasarım kuramlarının etkisini değerlendirmek amaciyla kentsel form çalışmaları yapan Fransız ekolü ise kentlerin nasıl inşa edilmesi gerektiğini araştırır. Lefebvre başta olmak üzere farklı sosyal bilim görüşlerinden etkilenen sosyal
Fransız kentsel morfoloji ekolü - Yöntemin temel bileşenleri (Tezer, 2019).
Q konut üretimi konut üretimi

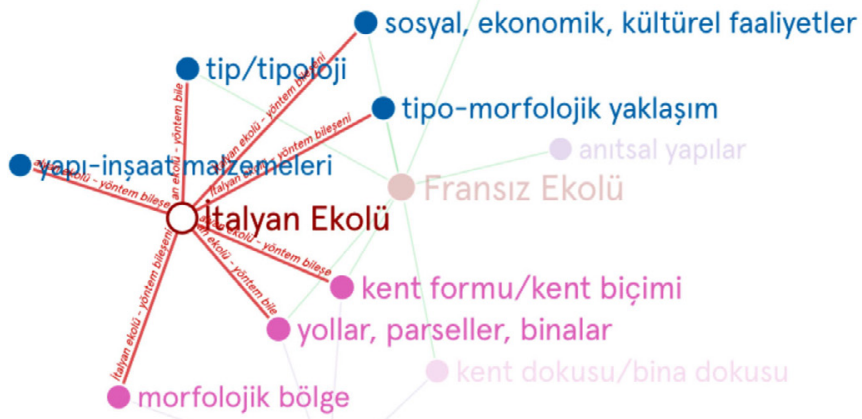

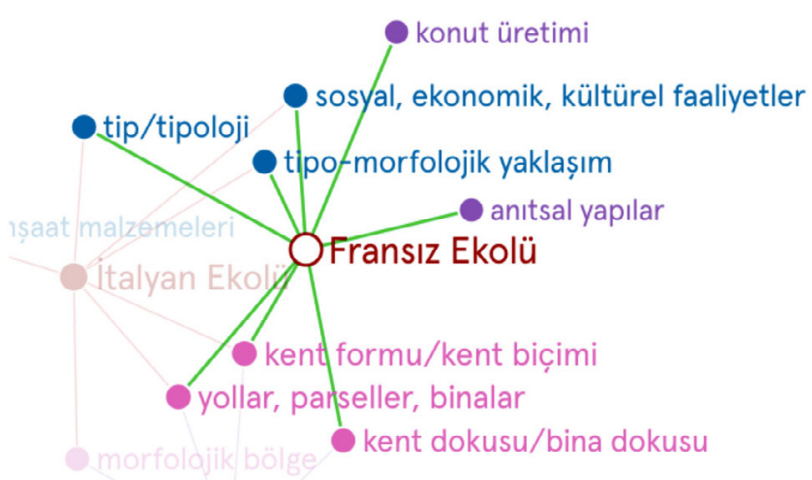




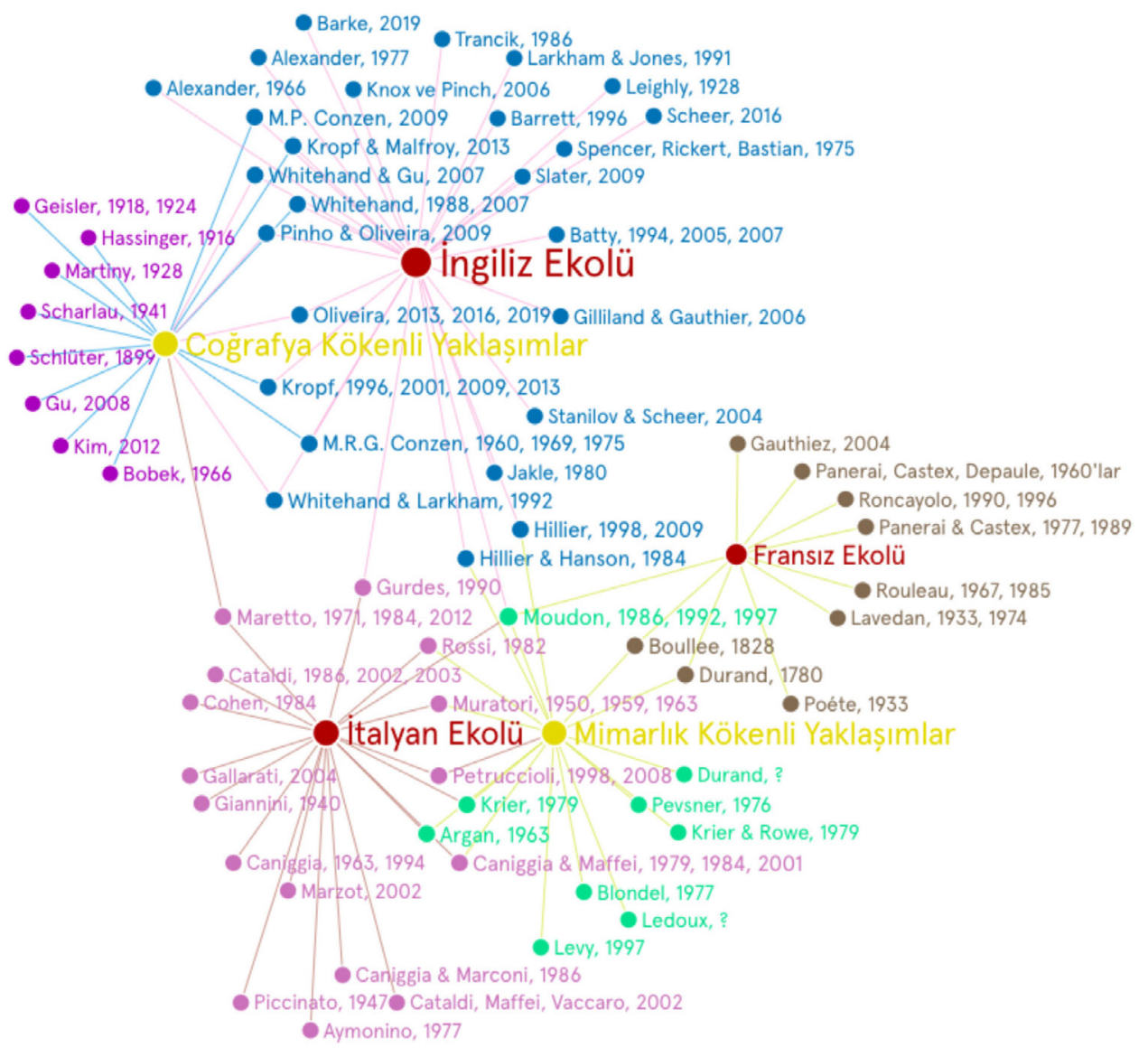

bilimciler, mimarlar ve şehir plancılarının etkin olduğu ekolün temsilcileri Panerai, Castex ve Depaule olarak bilinmektedir (Moudon, 1997).

Yerleşme tarihi analizi için önerilen yöntemsel çerçeve açısından kentsel morfoloji disiplininin katkısi; yerleşme ve çevresinin ulaşım altyapısı, makroform, kentsel mekânsal unsurlar, mülkiyet yapısı, yerleşmeler arası ilişkilerin incelenmesine ilişkindir. Kentin fiziksel yapısının çözümlenmesi konusunda İngiliz kentsel morfoloji ekolünde yollar, parseller ve binalardan oluşan kent planı, bina dokusu, arazi kullanımı, kentsel çeper kuşak, parsel döngüsü, kent formu, birim plan, eşik hattı ve morfolojik bölge ön plana çıkmaktadır (Conzen, 1959; Whitehand, 1988). İtalyan ekolünde tip/tipoloji, tipomorfolojik yaklaşım, morfolojik bölge, yapı malzemeleri, binalar ve açık alanları, kent biçim ve yapısı ile sosyal, ekonomik ve kültürel faaliyetler belirleyici olurken; Fransız ekolünde tipo-morfolojik yaklaşım, bina tipleri, kent biçimi, konut üretimi, öğelerin tipolojisi, anıtsal yapılar, kent formu ve kent dokusu (Muratori, 1959; Caniggia\&Maffei, 2001; Moudon, 1994) incelenmektedir (Sekil 5).

Daha öz bir ifadeyle kentsel morfoloji yönteminin yerleşme tarihi analizi için sunduğu imkân, kentsel morfoloji yöntemiyle yapılan çalışmaların yerleşmelerin fiziksel mekânının incelenmesi için sistematik bir altlık oluşturmasıdır. Özellikle İngiliz kentsel morfoloji ekolünün kurucusu olan Conzen'in kentsel morfoloji yaklaşımıyla

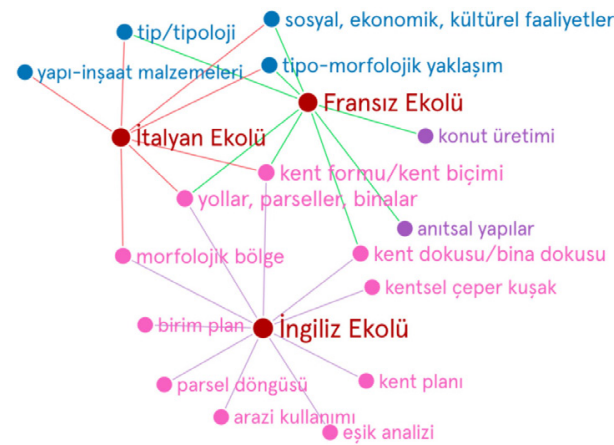

Sekil: 4

Kentsel morfolojide yaklaşımlar ve ekoller (Tezer, 2019).
Sekil: 5

Kentsel morfoloji ekollerinin temel yöntem bilesenleri (Tezer, 2019). 
yapılan incelemeler, kentlere ilişkin pek çok değişkenle birlikte değerlendirilebilecek çok katmanlı bir altlığı oluşturmaktadır. Bu yaklaşım biçimi, bu çalışma çerçevesinde kullanılacak kentsel morfoloji bileşenlerinin tespit edilmesinde belirleyici olmuştur. Bu çalışma kapsamında kentsel morfoloji yönteminin bileșenleri, yerleșme tarihi analizi yönteminin bileşenlerinden doğal fiziki unsurlar, ulaşım altyapısı, makroform ve kentsel mekânsal unsurların incelenmesine yöntemsel açıdan olanak sağlamaktadır.

Kentsel morfolojinin bu çalışma kapsamında yönteme katkısının tespit edilmesinin ardından, hedeflenen yerleşme tarihi analizi yöntemi çerçevesinin oluşturulabilmesi için kentsel morfoloji yönteminin hangi açılardan yeterli olmadığı ve tamamlanmas1 gerektiğinin tespitine sıra gelmiştir. Bu aşamada öncelikle "ölçek" meselesi ön plana çıkmakta, Ünlü ve Baş'ın (2015) kentsel morfolojide ölçek konusuna ilişkin olarak yakın dönemde yaptığı bir çalışmadaki yaklaşımın, kentsel morfoloji yaklaşımında ölçek konusuna ilişkin genel bir fikir verdiği düşünülmektedir. Müdahale ölçeğinin akış yönünü alt ölçekten üst ölçeğe doğru tarifleyen çalışmada üst ölçek kenti, orta ölçek mahalleyi, alt ölçek ise binayı ifade etmekte; üst ölçekte kentsel büyüme örüntüsü, orta ölçekte yapı adası/sokak örüntüsü ve alt ölçekte parsel/bina örüntüsü incelenmektedir (Ünlü\&Baş, 2015, 16). Kentsel morfoloji yaklaşımında üst ölçek, kent bütününü ifade etmekte ve kent formuna ilişkin incelemeler "üst ölçekli incelemeler" olarak çalışmaya dahil olmaktadır.

Bu noktada ölçek meselesinden hareketle yerleşmelerin üst ölçekle ilişkileri açısından, ilişkisel tarih bakışı, insan unsurunun yerleşme tarihi içinde ele alınışı ve "bölge" referanslarıyla tarihsel coğrafya, yardımcı/tamamlayıcı yöntem olarak ön plana çıkmıştır. Burada farklı yöntemsel yaklaşımların kavramları kullanma biçimine değinmek gereklidir. Örneğin "bölge" bileşeni tarihsel coğrafya ve kentsel morfoloji çalışmalarını ilk defa biraraya getiren Conzen'in analizinde (Conzen, 1959) baz1 kısımlarda coğrafi bölgeye, bazı kısımlarda kent makroformuna, bazı kısımlarda ise morfolojik bölgeye 4 karşllık gelmekte ve üst ölçekli analizi ağırlıklı olarak morfolojik bölge ölçeğinde yapılan değerlendirmeler oluşturmaktadır. Bu aşamada, kenti pek çok değişkeniyle etraflıca incelemeye olanak sağlayan kentsel morfoloji disiplininin, kentin üst ölçekli bağlamı ve insan unsurunun kentle etkileșimini eksik bıraktığına dair bir tespit gerekli görülmektedir. Yerleşme tarihi analizini odağına yerleştiren bu çalışma kapsamın$\mathrm{da}$, yerleşmenin tarihsel gelişiminin üst ölçekli ilişkilerinden bağımsız incelenmesi olanaksız görülmektedir. Burada üst ölçekli inceleme yöntemi hem bölgesel ölçek hem de "teritoryal ilişkiler" üzerinden kurularak; coğrafi bölgeyle kimi zaman örtüşen, kimi zaman ise yalnızca tematik referanslar üzerinden belirlenen bir ilişkiler sistemi üzerinden hareket etmektedir.

\subsection{Tarihsel Cŏgrafya Yöntemi}

Yerleşme tarihi analizi için yöntemsel bir çerçeve oluşturulması için kentsel morfolojinin sunduğu fiziksel analiz bileșenlerinin yanında ihtiyaç duyulan kavramların büyük bir bölümü, tarihsel coğrafya disiplini içinde yer alan veya onunla ilişkilenen kavramlardır. Bölgesel coğrafya yaklaşımları arasında yer alan "tarihsel coğrafya", bu çalıșmada hedeflenen çerçeve için kentsel morfoloji yönteminin eksik bıraktığı ilişkisellik, ölçek, teritoryalite ve insan unsuruna dair kavrayışı nedeniyle uygun görünmektedir.

AAG'nin 5 tanımında "Tarihi coğrafyacılar, geçmiş zamanların coğrafyasını yeniden inşa etmekle/yaratmakla ilgilenirler. Bunu yaparken, günümüz coğrafyasını anlamak için tarihçiler ve arşivcilere katkıda bulunarak onların yöntem ve tekniklerine çok yakın çalışırlar" ifadeleri yer almaktadır (Cultural Human Geography, 2019). "Geçmişin coğrafyası" olarak tanımlanan ve 1700 y1lında kurulduğu kabul edilen tarihsel coğrafya alanı, 1700 ve 1920-1930 yılları arasında "klâsik tarihi coğrafya" dönemini yaşamış, 1920-1930 yıllarında bir disiplin olarak yükselmesiyle beraber "modern tarihi coğrafya" dönemine geçilmiştir (Mitchell, 1975, 12; Butlin, 1993, 24). Bu alanda 
1930-1960 arasında yapılan jeomorfoloji ve tarihi coğrafyaya dayalı çalışmalar, 1960-1970 arasında ampirik çalışmalar, 1970 'ten günümüze ise tarihi materyalizm ve idealizmin hümanist perspektifini yansitan çalışmalar olmak üzere üç evrede gelişmiştir (Jonston, 1997, 246-247). 1970 öncesi tarihsel coğrafya çalışmalarının ana konusunu oluşturan tarım toplumu ve arazi, 1970 sonrasında yerini şehir ve endüstri toplumuna bırakmıştır (Hamshere, 1987, 61-62; Gümüş̧̧ü, 2010, 205).

Tarihi coğrafyanın etki alanı, coğrafyanın diğer yan dalları ile karşılaştırıldığında zaman boyutu sebebiyle sınırsız görünmektedir. Araştırma sürecinde tarihi coğrafyanın temel konuları; geçmişin coğrafyası, kentsel peyzajın değişimi, "günümüzdeki geçmiş" ve coğrafi tarih olarak ortaya konulmaktadır (Pacione, 1987, IX). Tarihsel olayların üzerinde gerçekleştiği coğrafi mekânın kendisine has özelliklerini ve ortak nitelikleri açıklamayı amaçlayan tarihsel coğrafya; yollar, şehirlerin kuruluş ve gelişmesinde coğrafyanın yeri ve yerleşmeye dair diğer hususları incelemektedir (Baykara, 1995, 35). Tarihsel coğrafyanın araştırma konuları ve şehircilik çalışmaları çok katmanlılık açısından benzer niteliktedir. Geçmişteki insan faaliyetlerini coğrafi ilke ve metotlarla inceleyen tarihsel coğrafya araştırmasında mutlaka coğrafi gerçeklerin incelenmesi beklenmektedir. Araştırmadaki konu ve problemlerin yerinin, önceki ve mevcut gerçek dağıllşının belirlenmesi, fiziki coğrafyaya dair verilerin ortaya konulması gerekli görülmektedir (Mitchell, 1975, 12-13).

Tarihsel coğrafya yönteminde yerleşmeler üstü bir coğrafya tanımı yapılırken, kentsel morfolojide analizin ölçeği (krsal ve kentsel yerleşmeler arasındaki hiyerarşik düzene odaklanan istisnalar dışında) yerleşmeye, yani görece daralmış alanlara tekabül etmektedir. Zaman kategorisi ise bu iki yöntemi farklı ölçekler üzerinden birbirine bağlama olanağı sağlayan bir bileşendir. Yerleşme tarihi analizinin yapılabilmesi için kentsel morfolojinin sunduğu sistematik yerleşme altlığının desteklenmesinde tarihsel coğrafyanın kattığı ilk bileşen teritoryalite ${ }^{6}$ ve ilişkisel tarih düşüncesidir. Bu durum, tarihsel coğrafyanın da önerdiği "bir yerleşmenin çevresinden bağımsız ele alınamayacağı" yaklaşımıyla örtüşmektedir.

Bu çalışma kapsamında teritoryal ilişkiler ağırlıklı olarak iktisadi ve sosyal akışlar olarak ele alınmakta; ürün, para, sermaye, fikir, insan, inanç, kültür akışlarını içermektedir. Akışların teması, neye bağlı olduğu, nereden nereye bir akışın söz konusu olduğu, akışların nedeni, yoğunluğunun/seyrekliğinin ne anlama geldiği, akışın hangi toplumsal gruplar için, hangi amaçlar çerçevesinde ve ne için gerçekleştiği gibi olgularla birarada irdelenmesi; bu sayede yerel ve üst ölçek ilişkilerinin de kurulması, bir yerleşmenin tarihini anlamakta önemlidir. Üretim ve dolaşım alanı ilişkisi demiryolu, karayolu, liman altyapılarının kurulması ile açıklanırken; gümrük varlığı, vergilendirme durumu, para birimi ve akışı, teritoryalitenin tespit edilmesi için kullanılabilecek diğer göstergeleri oluşturmaktadır. İktisadi üretimi besleyen işgücünü oluşturan nüfusun kente yönlendirilmesi, fiziksel mekânın barınma ve çalışma yapılarının yerleştirilmesi için manipüle edilmesi sonucunu getirmektedir. Mekânın düzenlenmesi; kentin fizik mekânıyla beraber, kenti oluşturan nüfusa dair toplumsal ve ekonomik ilişkileri de içermektedir. Toplumsal ve ekonomik ilişkilerin fizik mekâna yansıması, hiyerarşinin mekâna yansımasını da beraberinde getirmekte, kentsel mekânda fiziksel açıdan birbirinden farklılaşan (kent dokusunun değişmesi nedeniyle kentsel morfolojinin alanına giren) yapısal görünümleri beraberinde getirmektedir.

Kentler her zaman bir üst kentler ağının/ sisteminin içinde, bu sistemin bir parçası olarak varlık göstermekte, bu durum kentlerin -yerleşme tarihi açısından- anlaşılabilmesi için, bir bölgesellik içinde ele alınması gerekliliğini oluşturmaktadır. $\mathrm{Bu}$ bakışla yerleşme tarihi çalışması bir etkileşim alanı olarak, ilişkisel bir tarih anlatısına dönüşmekte; bir yerleşmenin anlaşılabilmesi ancak, çalışmada odaklanılan tema/lar çerçevesinde karşılıklı etkileşim içinde olduğu kentler ile ilişkisel olarak ele alınmasıyla mümkün olmaktadır. ${ }^{7}$ Yerleş-
6 Bu çalışmada "teritoryalite" karşılığı olarak ele alınan "territoriality" kaurami tarihsel dönemlere ilişkisel bakı açısıyla bakılmasına olanak sağlamak üzere, coğrafya, bölge, ölseklerarası ilişkileri kapsayan dinamik bir kauramdir.

7 Örneğin, Braudel'in Akdeniz'i bir havza ve ilişkisel bir mekân olarak ele aldığı çalıșmaları (Braudel, 1949). 
me tarihine dair ilişkisel bir bakış açısı geliștirmek; akışlar ve akıș alanları üzerinden bir yerleşmeler sistemini anlamaya imkân vermekte, kent ölçeğinde ise maddi kültür unsurları, yerleşmeyi somutlaştıran çalışma için bir altyapı hazırlamaktadır. Akışlar; araştırmada odaklanılan temaya göre mal ve metalar, hammadde, sermaye, işgücü ya da nüfus gruplarının, dolayısıyla farklı kültürel akışların hareketini içerebilmektedir.

Yerleşme tarihi çalışmalarında çoğunlukla bir belirsizlik konusu olan ölçek meselesine kentsel morfoloji ve tarihsel coğrafya yaklaşımları farklı biçimlerde yaklaşmakta; kentsel morfolojide "üst ölçek" (Conzen, 1959) kavramı kentin makroformunu ifade etmek üzere kullanılmaktadır. Kapsamlı bir yerleşme tarihi analizinin yapılması için bir kentin incelenmesi sürecine makroform ile başlanması ise; yukarıda açıklanan teritoryal ilişki ve ilişkisellikleri anlamaya olanak sağlamamaktadır. Kentsel morfolojinin üst ölçek olarak ele aldığı makroforma dair incelemenin, önerilen yerleşme tarihi analizi çerçevesi içinde üst ölçek ve alt ölçek ilişkisinin kurulduğu bir ara kesit olan orta ölçekteki makroform incelemesini oluşturması uygun görünmektedir.

Yerleşme tarihi çalışmalarında genel eğilim yerleşmelere ilişkin verilerin kronolojik olarak bir dökümünün yapılması ve yorumlanmasıdır. Bu çalışmada yerleşme tarihi çalışmalarındaki genel eğilime ilişkin olarak eleştirilen kronolojik tarihin karşısına, mekânsal tarih yaklaşımı yerleştirilmektedir. Bu aynı zamanda, tarihsel süreçte farklı hızda değişimlerin yaşandığı coğrafi mekân ${ }^{8}$ (Braudel, 1949), kentlerin yapılı çevresi, iktisadi yapının değişimi gibi unsurların mekânsal veriler üzerinden eşzamanlı okumasına olanak sağlamaktadır. Coğrafyanın tarihsel süreç içinde geçirdiği; bazen kaynağını oluştururken bazen de maruz kaldığı ekolojik değişimler, doğal afetler, fizik mekânı değiştiren yangın gibi afetler, yerleşme nüfusunun bir bölümünü doğrudan etkileyebilen salgın hastalıklar, $\mathrm{vb}$ yerleşmenin sosyal ve fiziksel kompozisyonunda büyük değişimlere neden olan durumların tümü, ilişsisel inceleme yapmayı gerekli kılmaktadır. Öte yandan üretim ve taşıma teknolojisinin zaman içinde gösterdiği değișimler de kentlerin ve kentler arası ilișkilerin geri dönülmez biçimde değişmesine, dönüşmesine neden olmaktadır.

Tarihsel coğrafya yaklaşımının, yerleşme tarihi analizi yöntemsel çerçevesine diğer bir katkısı ise "insan" unsuruna ilişkindir. Yerleşme tarihi çalışmalarında insan, kentteki nüfus büyüklüğünün, nüfus yoğunluğunun farklı dönemlerde gösterdiği değişim üzerinden çalışmaya dahil edilmekte, bunun sonucunda insanın kentin fiziksel mekânı üzerindeki belirleyici etkisi geri planda kalmaktadır. Halbuki sayısal bir nüfus verisi olmanın ötesinde insan, kentin sosyal, ekonomik, kültürel ve fiziksel tüm yapısal unsurlarının hem belirleyicisi hem de belirlenenini oluşturması açısından, yerleşmenin tarihsel sürecinin anlatısında büyük bir yer tutmaktadır. Ekonomik, toplumsal ve kültürel açıdan üreten, tüketen ve ilişki ağları içinde yeniden üretimi sağlayan temel bileşen olarak insan, kentin hem fiziksel hem de geniş anlamıyla toplumsal değişimini yönlendiren temel unsurlardan biri olarak görülmelidir. İnsan, hem teritoryal ilişkiler üzerinden akışlara konu olan, hem ilișkisel tarih bakıșı ile farklı biçimlerde bir aktöre dönüșen, hem de yerleșme üzerindeki belirleyiciliği ile kenti oluşturan ana unsurlardan biri olarak karşımıza çıkmaktadır.

Tarihsel coğrafya disiplininin burada önerilen yerleşme tarihi analizi yöntemsel çerçevesine katkısı; kentsel morfolojinin bir kent ya da kent parçası ölçeğinde, belirlenen bir dönem aralığına ilişkin olarak, büyük ölçüde fizik mekâna dair değerlendirmelerine ek olarak idari yapı, sınırların değişimi, siyasi gelişmeler, nüfus yapısı, iktisadi üretim biçimi, üst ölçekli doğal fiziki unsurlar, üst ölçekli ulaşım ilişkileri ve teritoryal ilişkilerin incelenmesi olanağıdır.

\section{Yerleşme Tarihi İçin Bir Çerçeve: Yöntemsel Olanaklar}

Yerleşme tarihi açısından yöntemsel yaklaşım sunan kentsel morfoloji ve tarihsel coğrafya disiplinlerinin kavramsal ve yöntemsel bileşenleri yukarıda tartışılmıştır. Tarihsel coğrafyanın yöntem bileşenleri;
Coğrafi mekân: Histoire immobile, long (Braudel, 1949). 


\begin{tabular}{|c|c|c|c|c|c|c|c|}
\hline & İngiliz Ekolü & İtalyan Ekolü & Fransız Ekolü & $\begin{array}{l}\text { Mimarlık Kökenli } \\
\text { Yaklaşımlar }\end{array}$ & Coğrafya Kökenli Yaklaşımlar & Tarihsel Coğrafya & $\begin{array}{l}\text { (Önerilen) Yerleşme Tarihi } \\
\text { Analizi Yöntemsel Çerçevesi }\end{array}$ \\
\hline \multirow{12}{*}{$\begin{array}{l}\text { yöntemin } \\
\text { bileşenleri }\end{array}$} & kent formu & \multirow{2}{*}{ kent formu } & \multirow{2}{*}{ kent formu } & \multirow{2}{*}{ tip/tipoloji } & \multirow{2}{*}{ kent formu } & \multirow{3}{*}{ iliş̧kisel / bakışımlı tarih } & makroform \\
\hline & birim plan & & & & & & nüfus yapısı \\
\hline & kent planı & \multirow{2}{*}{ tip/tipoloji } & \multirow{2}{*}{ tip/tipoloji } & \multirow{2}{*}{ tipomorfoloji } & \multirow{2}{*}{ kent tarihi } & & iktisadi üretim biçimi \\
\hline & kentsel doku & & & & & \multirow{2}{*}{ insan unsuru } & mülkiyet yapısı \\
\hline & arazi kullanımı & \multirow{2}{*}{ tipomorfolojik yaklaşım } & \multirow{2}{*}{ tipomorfolojik yaklaşım } & \multirow{3}{*}{ kentsel doku } & \multirow{3}{*}{ kent planı } & & siyasi ve yasal gelişmeler \\
\hline & binalar & & & & & \multirow{3}{*}{ teritoryalite } & idari yapı/tanım ve sınırlar \\
\hline & parseller & \multirow{2}{*}{ binalar ve açık alanlar } & \multirow{2}{*}{ kentsel doku } & & & & doğal fiziki unsurlar \\
\hline & yollar & & & \multirow{3}{*}{ arazi kullanımı } & \multirow{3}{*}{ arazi kullanımı } & & ulaşım altyapıSı \\
\hline & morfolojik bölge & \multirow{2}{*}{ morfolojik bölge } & \multirow{2}{*}{ konut üretimi } & & & & \multirow{4}{*}{ kentsel mekansal unsurlar } \\
\hline & kentsel çeper kuşak & & & & & ust olçek / Dolge & \\
\hline & parsel döngüsü & \multirow{2}{*}{ yapı malzemeleri } & bina tipleri & \multirow{2}{*}{ yapı bileşenleri } & \multirow{2}{*}{ kent coğrafyası } & \multirow{2}{*}{ lokalizasyon } & \\
\hline & eşik hattı & & anitsal yapilar & & & & \\
\hline yöntemin amacı & $\begin{array}{l}\text { Kentsel yapı kuramlarını } \\
\text { gelisstirmek için yapılan } \\
\text { betimleyici ve açıklayıcı } \\
\text { çaıışmalar. }\end{array}$ & $\begin{array}{l}\text { Kentsel tasarım teorisini } \\
\text { geliştirmek üzere yapılan } \\
\text { tanımlayııı çalışmalar. }\end{array}$ & $\begin{array}{l}\text { Kent yapılarında geçmiş } \\
\text { tasarım kuramlarının } \\
\text { etkisini değerlendirmeyi } \\
\text { amaçlar. }\end{array}$ & $\begin{array}{l}\text { Yapılı çevrenin tipolojik } \\
\text { analizi, tipolojk süreç- } \\
\text { kentsel doku ilişkisi ve } \\
\text { değişimi. }\end{array}$ & $\begin{array}{l}\text { Yerleşmeleri tanımlamak, } \\
\text { tarihsel geliş̧imi, form ve işlev } \\
\text { değişim süreçleini incelemek. }\end{array}$ & $\begin{array}{l}\text { Tarihsel olayların gerçekleştiği } \\
\text { coğrafi mekanın özelliklerini } \\
\text { açıklamak. }\end{array}$ & $\begin{array}{c}\text { Ölçeklerarası, zamanlararası ve } \\
\text { temalar arası bir bakış açısılyla, } \\
\text { kentsı morfoloji ve tarihsel } \\
\text { coğrafya yardımılla yerleșme } \\
\text { tarihi analizi yapmak. }\end{array}$ \\
\hline mesleki köken & Coğrafyacilar & Mimarlar & $\begin{array}{c}\text { Sosyal bilimciler, Mimarlar, } \\
\text { Sehir plancıları }\end{array}$ & Mimarlar & Cog̈rafyacılar & Coğrafyacılar & Çok disiplinli bir alan \\
\hline önemli isimler & $\begin{array}{l}\text { M.R.G. Conzen, } \\
\text { Whitehand, Kropf, } \\
\text { Larkham, Hillier }\end{array}$ & $\begin{array}{l}\text { Muratori, Caniggia, Rossi, } \\
\text { Maffei, Cataldi }\end{array}$ & $\begin{array}{l}\text { Lefebure, Panerai, Castex, } \\
\text { Depaule, Gauthiez }\end{array}$ & $\begin{array}{l}\text { Muratori, Caniggia, Argan, } \\
\text { Rossi, Krier, Moudon, Hillier }\end{array}$ & $\begin{array}{l}\text { M.R.G. Conzen, Kropf, } \\
\text { Whitehand, M.P. Conzen, } \\
\text { Larkham, Maretto, Kim, Gu }\end{array}$ & $\begin{array}{l}\text { Gilbert, Butlin, Darby, Mitchell, } \\
\text { Hamshere, Sauer }\end{array}$ & - \\
\hline $\begin{array}{l}\text { amaç, köken, } \\
\text { isim için } \\
\text { referanslar }\end{array}$ & \multicolumn{3}{|c|}{ Moudon, 1997 kaynağı temel alınarak geliştirilmiştir. } & \multicolumn{2}{|c|}{$\begin{array}{l}\text { Moudon, } 1994 \text { ve Cömert, } 2013 \text { kaynakları temel alınarak } \\
\text { geliştririlmişstir. }\end{array}$} & $\begin{array}{l}\text { Gümüş̧̧ü, } 2010 \text { kaynağı temel } \\
\text { alınarak geliştirilmişşir. }\end{array}$ & $\cdot$ \\
\hline
\end{tabular}

yerleşme tarihi analizinin üst ölçeğini oluşturan bölgesel ilişkiler, teritoryal ilişkiler ve sosyal yapıyı oluşturan "insan" unsuru konuları incelenerek yöntemin yardımcı kavramları olarak ele alınmıştır. Kentsel morfoloji ve tarihsel coğrafya disiplinlerinin ışığında kurgulanan bu yerleşme tarihi analizi önerisinin yöntem-bileşenler ilişkisi, aşağıdaki çizelgede gösterilmiştir (Şekil 6).

Çizelgede İngiliz, İtalyan ve Fransız kentsel morfoloji ekolleri, kentsel morfolojiye coğrafi ve mimarlık temelli yaklaşımlar, tarihsel coğrafya disiplini ve bu makale kapsamında önerilen yerleşme tarihi analizi yöntemsel çerçevesi birarada değerlendirilmiştir. Bu değerlendirmede her yaklaşımın benimsediği yöntem(ler)in temel bileşenleri, yöntemin amacı, mesleki köken ve alanın önemli isimlerine yer verilmiştir. Çizelgede kullanılan renkler, kentsel morfoloji ve tarihsel coğrafya yöntemlerinin hangi bileşenlerinin burada önerilen yerleşme tarihi analizi yöntemsel çerçevesinin bileşenlerini oluşturduğunu ifade etmektedir.

Bu kavramlara ulaşmak için; kentin tarihsel gelişimini coğrafi bakış ile ele alan tarihsel coğrafyanın yaklaşımı ile Conzen başta olmak üzere farklı kentsel morfoloji ekollerinin kentin fiziksel biçimlenmesini kavramak için geliştirdiği yaklaşımlar, bu çalışma içinde ilişkisellik arayışı ile bir araya getirilmiştir. Kentin büyük ölçüde fiziksel nitelik taşıyan sistematik bir altlı̆̆1nın hazırlanması işi kentsel morfoloji yöntemiyle sağlanırken eksik kalan ilişkisel tarih, insan unsuru, teritoryalite, üst ölçek/ bölge konuları da tarihsel coğrafyanın bileşenleri olarak yerleşme tarihi analizi çerçevesine dahil edilmiștir. Ardından birbiriyle içerik açısından ilişkili olan bileşenler aynı potada eritilerek yerleșme tarihi analizi bileșenleri oluşturulmuştur. Yerleşme tarihi analizine ilişkin bu yöntemsel öneride; coğrafya/konumlar arası, ölçekler arası, zamanlararası, temalar/sektörler/hammadde kaynakları ve pazarlar arası ilişkiler olmak üzere farklı düzey ve temalar arasında ilişkisellik arayışları söz konusudur. Buna göre, bir yerleşmenin tarihini anlamada, mekânsal ve toplumsal etkenler ve belirleyicilerin, farklı ölçeklerde ve ilișkisellikleri içinde ele alınması gerektiği görülmektedir. Yerleşme tarihi analizinin iki bileşeninden ilki yazılı kaynaklara dayalı oluşturulan yerleşme tarihi analizi tablosu iken, diğer bileşeni harita ve görsel veri analizi oluşturmaktadır. Yerleşme tarihi analizi tablosunda üst ölçekli bakışla akışlar, ilişkiler ve verilerin karşılaştırılmasına dair idari yapı, tanım ve sınırlar, siyasi ve yasal gelişmeler, nüfus yapısı ve iktisadi üretim biçimini anlamaya yönelik bileşenler yer almaktadır. Tablonun alt ölçekli bileşenleri ise tüm mekânsal değişimlerin içinde gerçekleştiği çanağı oluşturan doğal fiziki
Şekil: 6

Kentsel Morfoloji - Yerleşme Tarihi - Tarihsel Coğrafya Bileşenleri llişkisi (Tezer, 2020). 
Tablo: I

Yerleşme tarihi analizi için veri dökümü tablosu (Tezer, 2019).
Tablo: 2

Yerleşme tarihi analizi bileşenleri tablosu (Tezer, 2019).

\begin{tabular}{|c|c|c|c|}
\hline Ölçekler & Bileşenler & İçerik & $\begin{array}{l}\text { Zaman / } \\
\text { Tarihsel dönem }\end{array}$ \\
\hline Ü1 & idari yapı/tanım ve sınırlar & $\begin{array}{l}\text { territoriality, bölgesel aidiyetler, coğrafi tanımlar, mevkii } \\
\text { isimleri, idari birimler, yönetim biçimi, sınır öğeleri, eşikler }\end{array}$ & \\
\hline Ü2 & siyasi ve yasal gelişmeler & $\begin{array}{l}\text { devlet gelirleri, ekonomik imtiyazlar, para birimi, vergiler } \\
\text { (şahsi/etnik ve ticari), savaşlar, istilalar, antlaşmalar }\end{array}$ & \\
\hline Ü3 & nüfus yapısı & $\begin{array}{c}\text { nüfus büyüklüğü, nüfus çeşitliliği, etnik yapı, dil ve inanç } \\
\text { deseni, göçler ve iskan }\end{array}$ & \\
\hline Ü4 & iktisadi üretim biçimi & $\begin{array}{c}\text { hammadde varlığı, hakim sektörler, başlıca üretim } \\
\text { konusu/biçimi, zanaatler, ticaret yolları, ticaret yapılarının } \\
\text { mekandaki dağılışı }\end{array}$ & \\
\hline A1 & doğal fiziki unsurlar * & $\begin{array}{l}\text { tarım alanı, orman alanı, yeşil alan, su varlığı, iklim; doğal } \\
\text { afetler (deprem, sel, vb) }\end{array}$ & \\
\hline $\mathrm{A} 2$ & ulaşım altyapısı * & bağlantı yolları, ulaşım deseni & \\
\hline A3 & makroform * & $\begin{array}{l}\text { yerleşmenin alan büyüklüğü, kent formu, büyüme yönü, } \\
\text { kentin yer seçimi, kentin girişleri }\end{array}$ & \\
\hline A4 & $\begin{array}{c}\text { kentsel mekansal unsurlar } \\
*\end{array}$ & $\begin{array}{l}\text { maddi kültür unsurları, yapı-parsel-yapı adası-alt bölge- } \\
\text { bölge ilişkisi, kent dokusu, anıtsal yapılar, anıtsal yapılar, } \\
\text { yapım malzemeleri, fonksiyon alanları, kamusal mekanlar, } \\
\text { mezarlıklar, arkeolojik alanlar ve yapılar, konut dokusu }\end{array}$ & \\
\hline A5 & mülkiyet yapısı & $\begin{array}{c}\text { mülkiyet deseni, tapu-kadastro sistemi, özel-kamu mülkiyeti } \\
\text { ayrımı, mülkiyetin etnik dağılımı }\end{array}$ & \\
\hline
\end{tabular}

\begin{tabular}{|c|c|c|c|c|c|c|}
\hline & \multicolumn{6}{|c|}{ Akışlar ve iliş̧kiler } \\
\hline \multirow{7}{*}{ 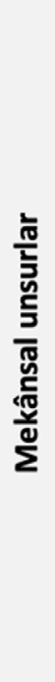 } & Ölçekler & Üst ölçek & Ü1 & Ü2 & Ü3 & Ü4 \\
\hline & Alt ölçek & İçerik & $\begin{array}{l}\text { idari yapı, tanım } \\
\text { ve sınırlar }\end{array}$ & $\begin{array}{c}\text { siyasi ve yasal } \\
\text { gelişmeler }\end{array}$ & nüfus yapısı & $\begin{array}{c}\text { iktisadi } \\
\text { üretim biçimi }\end{array}$ \\
\hline & A1 & $\begin{array}{l}\text { doğal fiziki } \\
\text { unsurlar* }\end{array}$ & & & & \\
\hline & A2 & ulaşım altyapısı* & & & & \\
\hline & A3 & makroform* & & & & \\
\hline & A4 & $\begin{array}{l}\text { kentsel } \\
\text { mekansal } \\
\text { unsurlar* }\end{array}$ & & & & \\
\hline & A5 & mülkiyet yapısı & & & & \\
\hline
\end{tabular}

unsurlar, ulaşım altyapısı, makroform, kentsel mekânsal unsurlar ve mülkiyet yapısını anlamaya ilişkin bileşenler olarak belirlenmiştir. Mülkiyet yapısı dışındaki bütün alt ölçekli unsurlar, harita incelemesinde ele alınarak, yapılan çıkarımlara tabloda yer verilmektedir.

Bu tabloların amacı, bir kentin tarihsel gelişimini anlamada önemli olan kavramları sunan ilişkiler ile kentin mevcut coğrafi koşul ve olanakları arasındaki ilişkileri kurarak, toplumsal öğelerin mekânsallaşmasının izlerini kavrayabilmektir. Bu nedenle öncelikle her bir bileşen ayrı ayrı incelenmekte ve ilişkiselliğin kurulduğu yerleşme tarihi analizi bileşenleri tablo- 


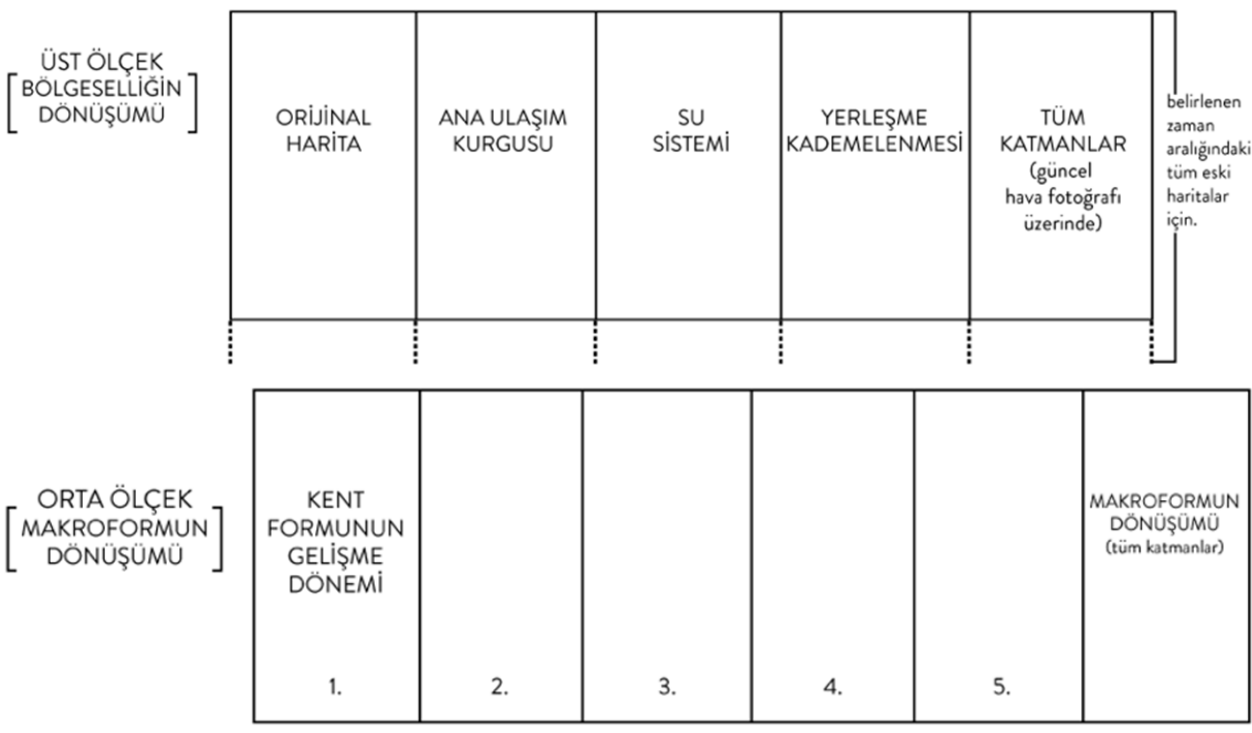

sunun hazırlanması için öncelikle alana ilişkin yazılı ve görsel veriler veri dökümü tablosuna işlenmektedir (Tablo 1). Bu yaklaşımda, mekânsal unsurlar ile akışlar ve ilişkiler arasındaki etkileşimin kavranması önem taşımaktadır (Tablo 2). Bu yaklaşım, bir yerleşmenin gelişiminde hangi unsurların dönemsel olarak diğer unsurlarla nasıl bir etkileşim içinde olduğunun kavranabilmesini sağlamaktadır. Öte yandan yerleşme tarihi çalışmalarında eksikliği duyulan görsel-yazılı kaynakların ilişkili olarak incelenememesi sorununa dair bir çözüm önerisi sunulmaktadır.

Yerleşme tarihi analizi çerçevesinin diğer aracı olan haritalar, tarihsel coğrafya ve kentsel morfoloji çalışmaları içinde farklı önemlere sahiptir. Haritalara yalnızca yeryön tarifi, lokasyon tespiti gibi nedenlerle ihtiyaç duyan tarihsel coğrafyadan farklı olarak kentsel morfoloji, alana dair yapılan incelemeyi harita üzerinde gerçekleştirmekte, dolayısıyla harita kentsel morfoloji çalışmasının temel aracını oluşturmaktadır. Yerleşme tarihi analizi yapılacak olan yerleşmeye ilişkin eski ve güncel harita, plan, çizim, fotoğraf, gravür benzeri görsel veriler ile bu verilere erişilemediği durumda hafızaya yönelik rehberli turlar, sözlü tarih, algı haritası çalışması gibi yöntemlerle oluşturulacak görsel malzeme ${ }^{9}$ çalışmanın mekânsal anlatımının kaynağını oluşturmaktadır. Harita incelemesiyle dönemler ve ölçekler arası değişimlerin yo- rumlanabilmesi için dört farklı türde harita hazırlanması gerekmektedir:

Birinci tür harita, yerleşme tarihi analizi için belirlenen örnek alanın içinde yer aldığı bölgesel coğrafyayı içeren bir çerçevede, üst ölçekli tarihsel haritalar üzerinden yapılan; ulaşım altyapısı, doğal fiziki unsurlar (topoğrafya ve su kaynakları), yerleşme kademelenmesinin değişim/ dönüşüm süreçlerinin izlendiği görsel malzemedir (Şekil 7). Çalışmanın üst ölçekli görsel verisinin oluşturulmasinda, tarihsel ve güncel bölgesel haritalar ile güncel hava fotoğrafi birarada kullanılmaktadır. Bu aşamada, yerleşme tarihi çalışmalarının temel zorluklarından olan veri eksikliği, bazı haritaların tarihine erişilememesi gibi sorunlara rastlanması mümkündür. $\mathrm{Bu}$ durumda coğrafi ve fiziksel veriler yazılı belgeler ve önceki/sonraki dönem haritaları karşılaştırılarak net bir tarih yerine bir dönem aralığ tespit etmek gerekmektedir.

Burada yalnızca ulaşım altyapısı, doğal fiziki unsurlar ve yerleşme kademelenmesi (yerleşme lekesi/makroform, yerleşme adl/puntosu, madde iminin büyüklüğü, merkez yerleşmelerin nüfus büyüklü̆̆̈̈, kır-kent ilişkisi/eklemlenmesi) katmanları üzerinden hazırlanan şematik haritalar hem temalar üzerinden tarihsel bir karşılaştırma yapılmasında kullanılmakta, hem de yerleşme tarihi analizi bileşenleri tablosunun tematik ve tarihsel açıdan ilgili kısımlarına yerleştirilmektedir.
Şekil: 7

Haritaların Analiz Yöntemi - Üst Ölçekli Haritalar (Tezer, 2019).

\section{Şekil: 8}

Haritaların Analiz Yöntemi - Orta Ölçekli Haritalar (Tezer, 2019). 
Şekil: 9

Haritaların Analiz Yöntemi - Alt Ölçekli Haritalar (Tezer, 2019).

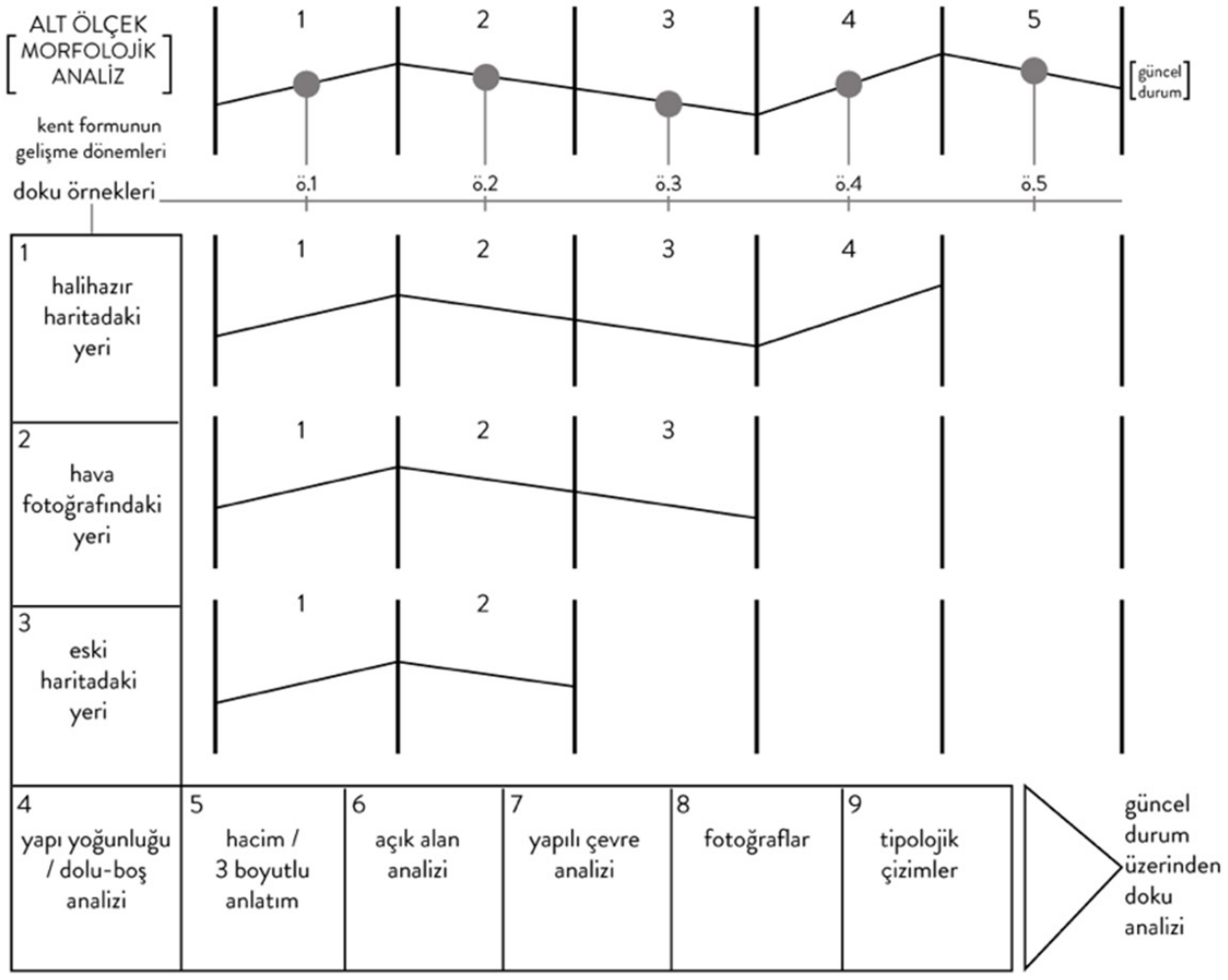

İkinci tür harita, çalışmada üst ve alt ölçekli görsel verilerin birbirine bağlandığı ara kesiti oluşturan makroform analizidir (Şekil 8). İncelenen yerleşmeye ilişkin üst ve alt ölçekli görsel verilerle örtüşen tarihlerdeki orta ölçekli harita ve hava fotoğrafları üzerinden yapılan yerleşme lekesi çizimlerini içermektedir. Bu değerlendirmede tarihsel süreçte yerleşmenin yayılım alanı, gelişme yönü ve değişimin büyüklüğü tespit edilmekte; yerleşmenin ana ulaşım ilişkilerinin de işlenmesi, yerleşmenin gelişme yönlerine ilişkin fikir vermektedir.

Üçüncü tür harita, yerleşmeye ilişkin alt ölçekli görsel veri incelemesini; kentsel morfoloji analizlerini içermektedir (Şekil 9). Kent bütününe dair çıkarımlar yapılan kentsel morfoloji incelemelerinde ağırlıklı olarak kentin morfolojik gelişme bölgeleri belirlenerek, bunlar içinden seçilen örnek dokuların morfolojik incelemesi yapılmaktadır. Kentsel gelişme dönemlerine göre farklı morfolojik bölgelerin izlenebildiği kentlerde ise, bu farklı bölgeleri kat eden bir rota önerilebilir. Ardından bu rotanın farklı dönemlerinden örnek dokular seçilerek, belirlenen dönem aralıklarındaki yapılaşma tipi ve niteliği güncel durum üzerinden belirlenmektedir.

Seçilen örnek dokuların sayısı, yerleşmenin büyüklüğü ve değişim dönemlerinin incelenmesinde tespit edilen farklılaşmalara göre belirlenebilir. Bu aşamada kent dokusunun; halihazır harita, hava fotoğrafi, tarihsel haritalar, yapı yoğunluğu, yapı adasının çevresinin açık alan analizi, yapı adalarının üç boyutlu çizimleri, alanda çekilen fotoğraflar, tipolojik çizimler üzerinden değerlendirilmesi mümkündür. Haritalar ve hava fotoğrafları üzerinde yapılan değerlendirmelerde, altlık haritaların aynı ölçekte olması veriler arasında karşılaştırma yapılabilmesi açısından önemlidir. Her morfolojik doku için yapı adası düzeyinde yapılan bu görsel analizlerin yanı sıra; inşa edildiği dönem/yıl aralığı, toplam alan büyüklüğü, yapı oturum alanı, sokak dokusunun niteliği, zeminin eğim/ topoğrafya niteliği, yapı adasındaki toplam yap1 sayıs1 ve kat adetleri, toplam yap1lı alan büyüklüğü ve yapıların tescil durumu bilgileri tespit edilmekte ve yazılı olarak aktarılmaktadır. Tüm bu verilerin işlendiği morfolojik analize ilişkin veriler, her bir 


\section{MORFOLOJIK ANALIZ / ÖRNEK DOKU 1}
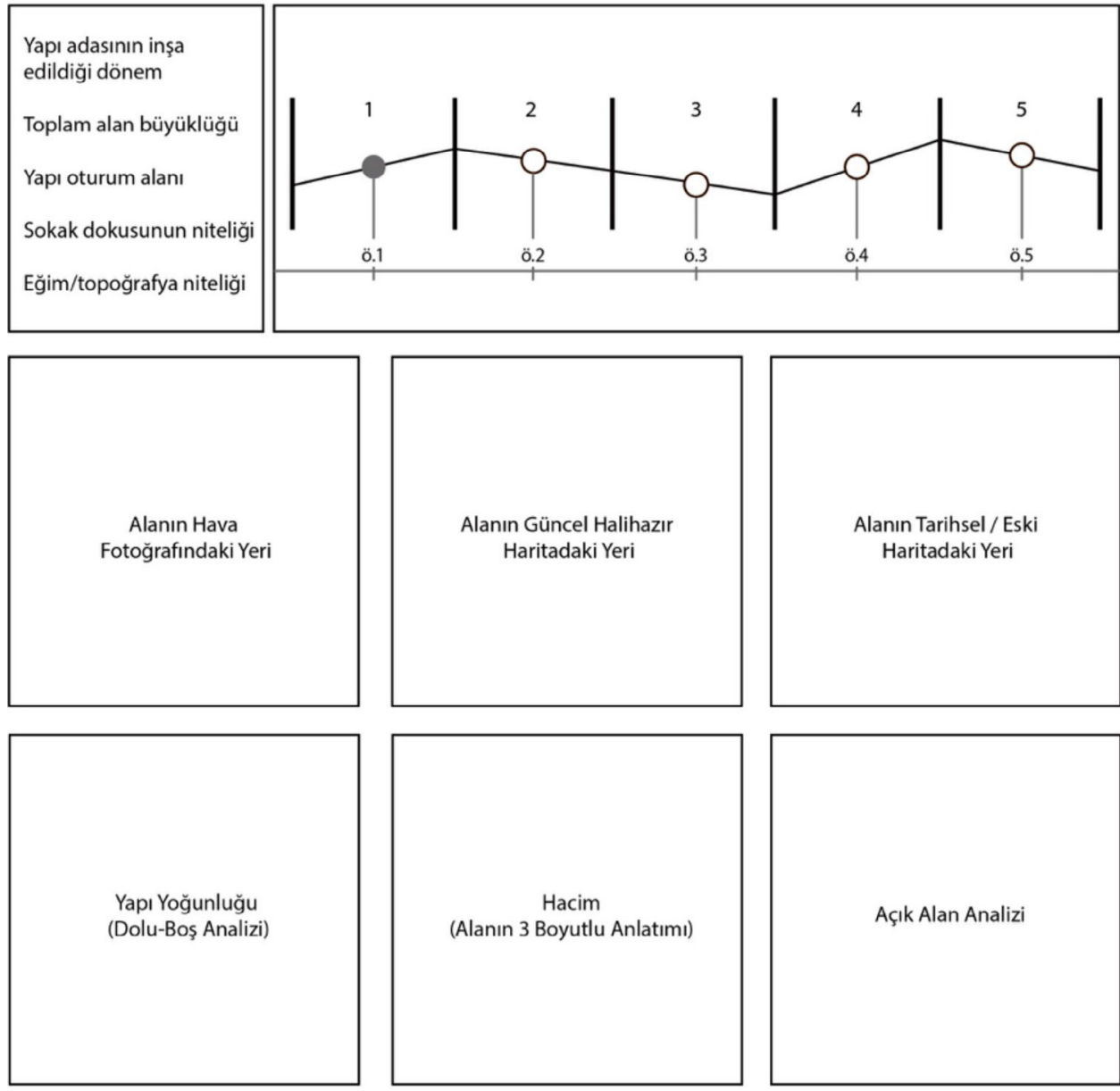

Dokunun Yapılaşma Nitelikleri

Yapı adasındaki toplam yapı sayısı

Yapıların kat adetlerine

göre dağılımı

Toplam yapılı alan büyüklüğü

Yapıların tescil durumu
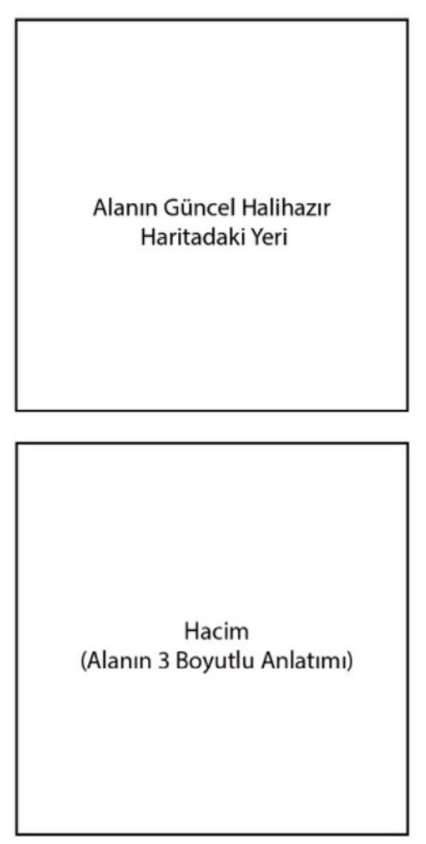
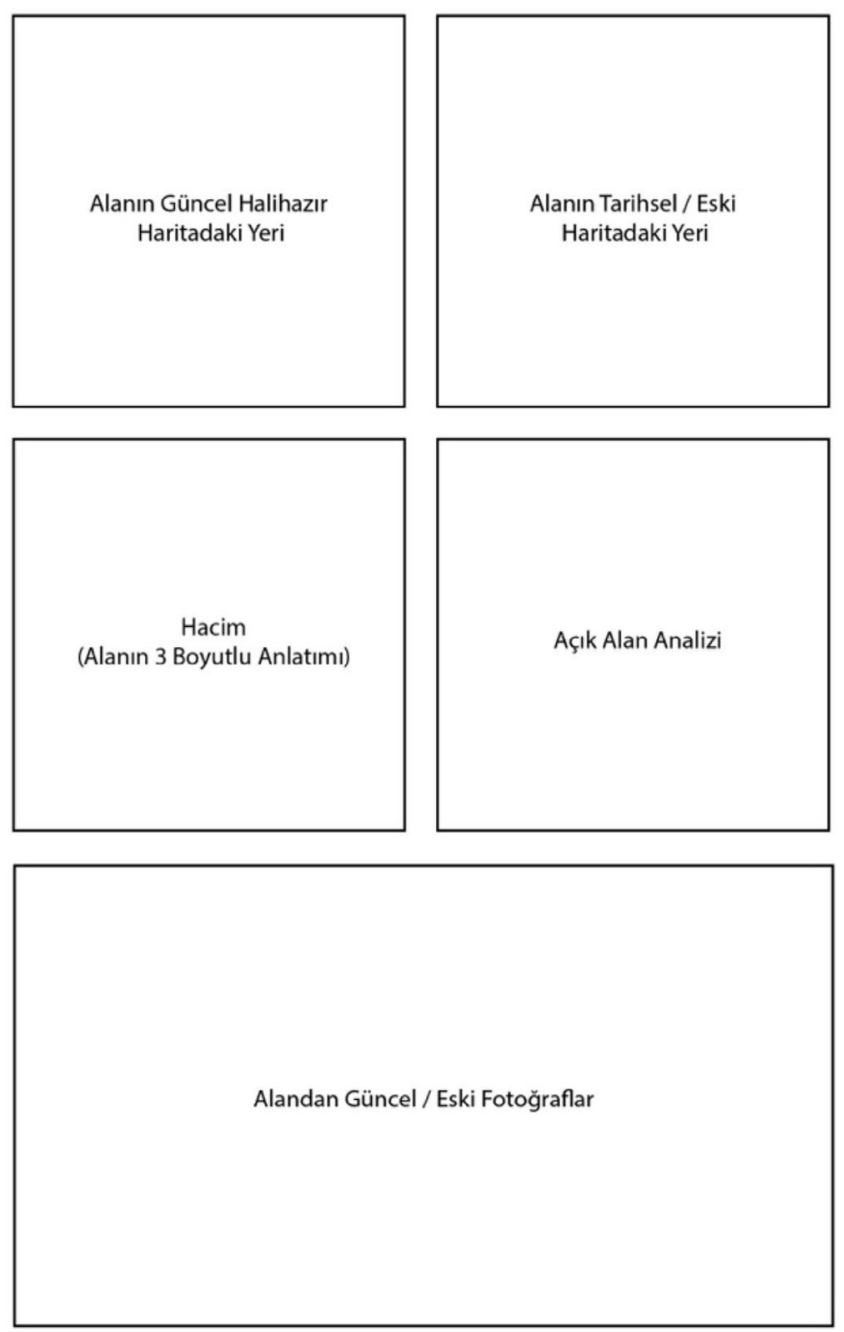

doku örneği için Şekil 10'da yer verilen örnek şemadaki gibi dizilerek birbiriyle karşılaştırılabilir ve yorumlanabilir morfolojik analizler tamamlanmaktadır.

$\mathrm{Bu}$ yaklaşım, yerleşmenin tarihsel gelişim öyküsünü fiziksel mekânla birlikte ele almaya olanak sağlamaktadır. Fakat bu yöntemsel yaklaşımın daha çok, tarihsel çekirdeğini korumuş olan ve bu tarihsel çekirdeğe eklemlenerek büyüyen kentlerde uygulanmaya uygun bir morfolojik analiz yöntemi olduğunu belirtmek gereklidir.

Dördüncü tür harita/şema ise, coğrafi konumlar ile her zaman tamamen örtüşmeyen teritoryal ilişkileri gösteren haritalar ve görsel malzemenin mevcut olmadığ 1 durumlarda hazırlanmaktadır. Bu şemalar
Şekil: 10

Haritaların Analiz Yöntemi - Alt Ölçekli

Analiz (Örnek sema) (Tezer, 2020). 
Sekil: "I

Haritaların Analiz Yöntemi - Teritoryal ilişki

analizi (Örnek sema) (Tezer, 2020).

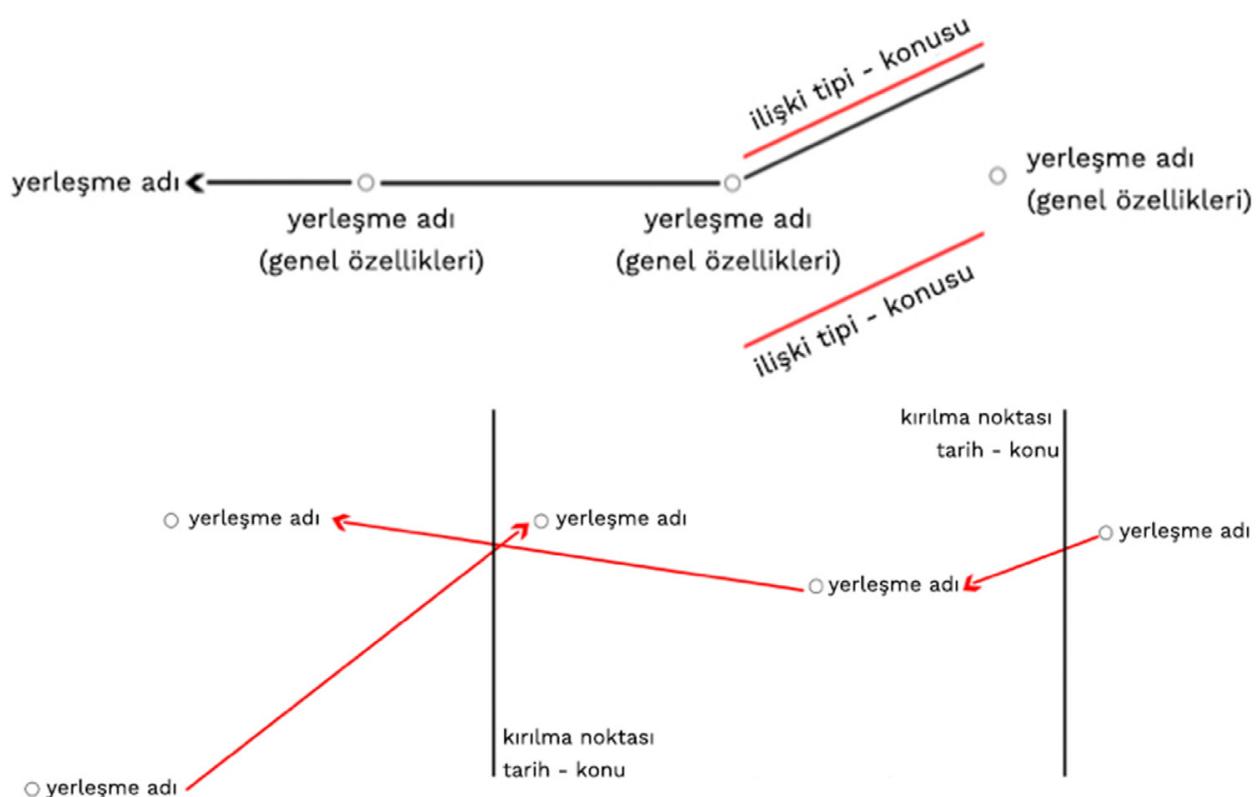

yazılı veriler üzerinden tematik olarak hazırlanması mümkün olan üst ölçekli ulaşım ağları, demiryolu sisteminin bütünselliği, tarihi ticaret yolları/ilişkileri, ticaret yap1lan yerleşmeler (hammadde, ürün, üretim biçimi, pazar, vb), limanlar ve su yollarının ulaştı̆̆ 1 noktalar, yönetimsel ilişkiler/bölgeselliğin dönüşümünü içeren şemalardan oluşmaktadır. Bu şemaların da hazırlanarak yerleşme tarihi analizi bileşenleri tablosunun ilgili kısımlarına yerleştirilmesi gerekmektedir. Aşağıda teritoryal ilişki şemalarına dair örnek şemalara yer verilmiştir (Şekil 11).

Yerleşme tarihi analizi yöntemsel çerçevesinin hedeflerinden biri farklı yerleşmelere de uygulanabilmesi olarak belirlenmiștir. Bu nedenle önerilen harita inceleme yönteminin kısıtlılıkları ve taşıdığı imkânların ele alınması, bundan sonra bu çerçeve ile yapılacak çalışmalar açısından önemlidir.

Önerilen yöntemsel çerçevenin temel özelliklerinden biri; coğrafi konumlar arasında, ölçekler arasında ve temalar arasında karş1laştırmalı bir yerleşme tarihi okuması yapmaya olanak sağlamasıdır. Bu okumanın yapılabilmesi için yazılı, sayısal ve görsel malzemeleri araştırma sürecine dahil etmek gerekmektedir. Bu çerçevenin farklı yerleşmelere uygulanabilmesine ilişkin en önemli kısıtlllıklardan ilki, büyük ölçüde tarihsel haritalardan oluşan görsel malzemenin temini ya da varolmasına ilişkindir.
Araştırma sürecinde yeterli görsel malzemeye ulaşılamaması hâlinde; yerele ilişkin yazılı tarih kaynaklarındaki mekânsal referans içeren ifadelere, bölge, konum ve mevki referanslarına bakılması; yakın geçmiş için yerelin hafızasını oluşturan "yaşlı" nüfusun aktör olarak yer aldığı hafıza ve algı rotaları yapılmasına; çalışmaya konu yerleşmenin yakın komşuluğunda bulunan görece merkezi nitelikteki yerleşmelere ilişkin tarihsel haritaların araştırılmasına ihtiyaç vardır. Bu yolla herhangi bir yerleşme için tarihsel dönemlere ilișkin ulaşım bağlantıları, topoğrafik sistem, su sistemi ve yerleşme kademelenmesi katmanlarını içeren tarihsel haritaların üretilmesinin ardından, burada önerilen çerçeveyi kullanmak mümkündür.

Yerleşme ve üst ölçek haritalarına dair diğer kısıtlılık, haritaların karşılaştırılabilir malzeme hâline getirilmesinde oluşmaktadır. Her dönemde farklı aktörler tarafindan, farklılaşan amaçlarla ve değişken katmanlarla hazırlanan haritaların birlikte değerlendirilebilmesi için mutlaka aynı bakış açısı ve ortak bir teknikle yeniden çizilmesi gereklidir. Bu yeniden çizimin yapılabilmesi için ortak bir coğrafya altlığının kullanılması, mekânsal referansa dair belirsizlikleri kaldırmakta, tarihsel haritalar altlığa işlenen verilerin dönemsel kaynağını oluşturmaktadır. Kullanılacak altlık için alanın güncel 
hava fotoğrafının tercih edilmesi, farklı dönem haritalarında coğrafi referanslarla ilgili olarak karşılaşılabilecek sorunların önüne geçilmesi açısından önerilmektedir.

Yerleşme tarihi analizi çerçevesinin oluşturduğu önemli bir imkân, "tematik yerleşme tarihi analizi”ni yapmaya olanak sağlaması, dolayısıyla verilerine ulaşılabilen tekil konular üzerinden yerleşmenin tarihsel geçmişini anlamaya imkân veren esnek bir yöntem oluşturulmasıdır. Verileri temalardan oluşan katmanlar hâlinde ele alan çerçevenin uygulama adımları sayesinde, yerleșmeleri oluşturan farklı katmanların tarihsel süreç içindeki değişimleri kendi içinde dönemlere göre incelenebilmektedir. Yerleşmenin su sisteminin, ulaşım sisteminin, yerleşme kademelenmesinin farklı ölçek ve dönemler içinde değişim takibinin yapılabilmesi, bu çalışmanın farklı yerleşmeler için tekrar edilmesi; tematik değişim karşılaştırmaları yapmaya olanak sağlayacaktır.

\section{Sonuc}

Bu çalışmanın önerdiği yöntemsel çerçeve yerleşmelerin tarihsel süreçte fiziksel, sosyal ve ekonomik boyutlarıyla birlikte sistematik biçimde değerlendirilmesine ilişkin bir imkân sunmaktadır. Analiz yönteminde kentsel morfoloji bileşenleri fiziksel mekânın mevcut durumu ve değişiminin çözümlenmesine olanak sağlarken, tarihsel coğrafyanın getirdiği sosyal ve üst ölçekli bakışla yerleşmenin tarihsel süreçte ve coğrafi bölgeselliği içinde nasıl bir tarihsel değişim süreci izlediği incelenmektedir. Bağımsız disiplinlerin bileşenleri çalışmaya yalnızca yerleşme tarihinin analiz edilebilmesi çerçevesinde dahil edilmiş olup, asıl amacı yerleşme tarihini analiz etmek olan yöntemsel çerçeve, detaylı bir kentsel morfoloji çalışması ya da derinlemesine bir tarihsel coğrafya okumasına dair bir iddia içermemektedir. Önerilen yöntemin herhangi bir yerleşmenin tarihsel bir dönem aralığına uygulanmasiyla elde edilecek görsel ve yazılı sonuç ürünler, o yerleşme üzerine yapılacak detaylı kentsel morfoloji analizi ve tarihsel coğrafya temelli derinlemesine çalışmalar için kaynak oluşturmaktadır.
Kentsel mekânın toplumsal, ekonomik faaliyetler, yer seçimleri, ulaşım ilişkileri, yeni konut alanlarının oluşmasıyla nasıl değiştiği konusunun incelenmesi de diğer bir potansiyel alanı oluşturmaktadır. Burada bölgesellik, makroformun değişim süreçleri ve farklı gelişme dönemlerini yapısal açıdan inceleme olanağı bulunmaktadır. Sosyal ve fiziksel ilişkilerin kentsel mekândaki somut, katılaşmış sonuçlarıyla ilgilenen kentsel morfolojinin bu çalışma içindeki yeri; kentsel makroformun değişimini anlamak, bu değişimi alt ölçekte önerilen rotadaki kent dokuları üzerinde incelemek olarak belirlenmiștir. Kentsel morfoloji incelemesinin daha ön planda olduğu bir analizde kentin işleyişine ve işlevlerine dair sisteme ilișkin incelemenin, bir ara ölçek olarak çalışmaya dahil edilmesi uygun olacaktır.

Tarihsel süreçle fiziksel mekânı eşzamanl1 kesen bir rota önerisiyle somutlaşan morfolojik inceleme; morfolojik bölgeleri ayrı ayrı ele almak yerine karakteristik tarihsel farklılıkları ön plana çıkarmayı amaçlamaktadır. Böylece bütün dönemleri, mekânları ve topoğrafyayı kesen bir rota oluşturulmakta; kent okuması morfolojik bölgeler yerine bu rota üzerinden yapılmaktadır. Yaygın görülen yaklaşımla morfoloji çalışmaları, seçilen bir parseli kendi gelişme dönemleri içinde gösterdiği değişim üzerinden incelemektedir. Burada yapılan morfolojik analizin, fizik mekânın arkaplanında sürmekte olan sosyal yapıya ilişkin değerlendirmelerle beslenmesi gerekmektedir. Bu ilișkinin bileșenler tablosunda yer alan mahalle-nüfus verileri ile kentsel morfoloji çalışması kapsamında incelenen kentsel dokular-mahalleler üzerinden kurulması mümkündür.

İçten dişa halkalar biçiminde (tarihsel çekirdeğini koruyarak) büyüme özelliği göstermeyen kentlerde tarihsel alt ölçekli incelemenin bir rota üzerinden yapılması uygun bir yöntem olmayabilir. Bu durumda çerçevenin uygulanabilmesi için; burada önerilen rotanın bir eşik hattı, çeper kuşak, vb bir temayla ilişkilendirilerek tespit edilmesi uygun olacaktır. Belirlenen rotanın kent makroformunun tarihsel süreçteki farklı 
gelişme dönemlerini mutlaka kesmesi gerekmektedir. Rotanın ilişkili olduğu kentsel dokular üzerinden kentin geçmişini incelemeye, dolayssiyla zamanlararası bir bakışa ve ölçeklerarası ilişkinin kurulmasına imkân vermesi beklenmektedir. Burada benimsenen rota yaklaşımı, kentsel morfolojinin genel anlayışından farklı olarak bir örüntüyü incelemek yerine yerleşmenin morfolojik değişim dönemlerine denk düşen ve onu kesen bir inceleme düzlemi sunmaktadır. Rota mekânda eşzamanlı olarak bir tarih okuması yapmaya olanak sağlamakta, dokunun incelenmesi, yerleşme tarihi analizi bileşenlerinden yalnızca birini oluşturmaktadır. Bu çalışmada yalnızca yerleşme tarihi analizinde gereken tüm ölçekler için, kentsel morfolojinin fiziksel mekâna dair inceleme yöntemleri çalışmaya dahil edilmiştir. Sonraki aşamada detaylı bir kentsel morfoloji çalışması yapılması, alt ölçekteki mekânsal değişimlerin yasal mevzuat, planlama durumu gibi dinamiklerle ilişkilendirilmesi mümkündür. Çalışmanın odağındaki ilişkisellik arayışı, kentte katılaşmış bir form olarak görülen fiziksel mekânın nasıl oluştuğunu açığa çıkarmayı amaçlamakta, günümüzdeki formun detaylı analizi bu yöntemsel çerçeve içinde görece tali bir yerde konumlanmaktadır.

Çalışmanın esas meselesi, farklı ölçeklerdeki tarihsel değişim süreçlerinin arkaplanını anlamak üzerine kuruludur. Bu çerçevede coğrafi konumlar, ölçekler ve temalar arasında karşılaştırmalı bir yerleşme tarihi okuması yapma olanağı vardır. Bu yöntemle yapılacak çalışmalara dahil edilecek yazılı, sayısal ve görsel malzemeler içinde, özellikle tarihsel haritalardan oluşan görsel malzemenin temini/varlığı önemli bir sınırı oluşturmaktadır. Bölgesel tarihi içinde önemli olan yerleşmelerin haritalarına erişim görece kolay olsa da, geri plandaki yerleşmeler için görece zor bir durum söz konusudur. Bu durumda görsel veri, bu çalışma yönteminin uygulanabilmesi açısından farklı görselleştirme ve yakın tarih için tarihsel alg1, hafıza rotası gibi harita yapma teknikleriyle oluşturulabilir. Haritacılığın henüz gelişmediği dönemler içinse bu yöntemsel yaklaşımın uygulanabilmesi için çalışılan döneme ilişkin yazılı kaynaklardan alınacak mekânsal referanslar üzerinden yapılacak harita ve şemalar, bu çerçevenin görsel malzemesini oluşturabilir.

Üst ölçekli harita değerlendirmesi, çalışmaya konu edilen yerleşmenin "tematik yerleşme tarihi analizi"ni yapmaya olanak sağlamakta, dolayısıyla verilerine ulaşabilen tekil konular üzerinden yerleşmenin tarihsel geçmişini anlaşılır hâle getirmektedir. Verilerin temalardan oluşan katmanlar hâlinde bu çerçevede yeniden ele alınmasıyla, yerleşmeleri oluşturan farklı katmanların tarihsel süreç içindeki değişimlerini kendi içinde dönemlere göre inceleme olanağı oluşmaktadır. Dolayısıyla bu yaklaşım, farklı yerleşmelerin tematik değişimi üzerinden karşılaştırmalar yapılmasını mümkün kılmaktadır. Haritaların incelenmesi sürecinde uygulanan yöntemde topoğrafya sistemi sabit bir veri olarak kabul edilirken; su sistemi, karayolu ve demiryolu sistemi ile yerleşme kademelenmesi tarihsel süreçte değişen veriler olarak ele alınmıştır. Haritaların kendi içinde değerlendirilmesi dışında hem su, ulaşım, yerleşme kademelenmesi olarak belirlenecek bir tema üzerinden tüm haritaların temsil ettiği dönemler için bir değerlendirme yapılması hem de bu tekil temaların gruplar hâlinde karşılaş̧tırmalı olarak çalışılması mümkündür.

$\mathrm{Bu}$ yöntemsel çerçevenin kullanılacağı çalışmalarda hazırlanan yerleşme tarihi analizi bileșenleri veri dökümü çizelgesinde öncelikle kronolojik bir veri dökümü yapılması ve dönemsel ayrımlarda yerleşmenin yönetimsel değişim dönemlerinin esas alınması gerekmektedir. Bu durumun yerleşme tarihi çalışmalarında -makalenin ilk kısmında- eleştirilen kronolojik ele alışa dair çelişkili bir durum oluşturduğu düşünülebilir. Fakat bu yaklaşım yalnızca verilere erişim ve veri dökümünün zaman faktörüyle birlikte işlemesi daha pratik olduğu için yerleşme tarihi analizi bileşenleri tablosunun altlığını oluşturan veri dökümü tablosu için geçerlidir. Çalışmanın önerdiği bileşenler tablosunda ise kronolojik değil, mekânlar ve temalar üzerinden bir tarihsel veri tasnifi uygulanmaktadır. 
Önerilen yerleşme tarihi analizinin bir yerleşmeye -bu detayda- uygulanabilmesi için bir dönem aralığı belirlenmesi gerekebilir. Bir yerleşmenin kurulduğu günden günümüze tüm tarihsel sürecinin incelendiği durumda, veri araștırması, tasnifi ve işlenmesinin gerektireceği zaman ve iş yükü nedeniyle, ayrıntı düzeyi açısından görece genel bir yerleşme tarihi okuması yapılması da mümkündür. Görsel, yazılı ve sayısal tarihi verilere erişim, geri plandaki tüm yerleşmeler için araştırma sürecinde büyük zorluklar çıkarmaya adaydır. $\mathrm{Bu}$ durum da çalışmada bir dönem aralığ belirlenmesinin kolaylaştırıcı olabileceğini göstermektedir.

Yerleşme tarihi analizi çerçevesinin sunduğu diğer imkân, bu yöntemin yerleşmenin niteliğine, araştırmacının uzmanlığı ve yaklaşımına, yerleşmeye ilișkin verilerin niteliğine göre esneklik olanağı taşımasıdır. Bu yöntemle bir yerleşme tarihi analizi yapilırken, anlatılan sebeplerin herhangi birinden kaynaklanacak biçimde çalışma kentsel morfoloji ya da tarihsel coğrafyanın ağırlığını taşıyabileceği gibi, yöntemin bileşenlerine dahil edilmemiş farklı bir yöntemin bir bileșeninin de analize dahil edilmek üzere ödünç alınmasının önünde herhangi bir engel bulunmamaktadır.

$\mathrm{Bu}$ yöntemin bir kentin yerleşme tarihini incelemek için kullanılmasıyla; kentin üst ölçekli bölgesel bağlamı ve alt ölçekli mekânsal bileşenlerini birarada inceleyen, elde edilen verileri ilişkisellikleri üzerinden değerlendiren sistematik bir yerleşme tarihi analizine erişilmesi mümkün görünmektedire

\section{Kaynakça}

Alexander, C., Ishikawa, S. \& Silverstein, M. (1977). A Pattern Language. New York: Oxford University Press.

Argan, G. C. (1962). On the Typology of Architecture. Architectural Design, 33

Baş, Y. (2010). Production of Urban Form As the Reproduction of Property Relations Morphogenesis of Yenișehir - Ankara. Doktora Tezi. Orta Doğu Teknik Üniversitesi Şehir ve Bölge Planlama Bölümü

Baykara, T. (1995). Tarih Araștırma ve Yazma Metodu, Akademi Kitabevi.

Bilsel, C. (2015). Kent Tarihi Araștırmalarında Mekanbilimsel Bir Yaklaşım Olarak Kentsel Morfoloji. Y. Baş \& S. Barut (Edt.), Türkiye Kentsel Morfoloji Sempozyumu: Temel Yaklaşımlar ve Teknikleri - Bildiriler Kitabı. Mersin: Mersin Üniversitesi Yayınları. (59-77).

Blondel, J.F. (1777). Cours d'Architecture, Paris: Desaint.

Bobek, H. (1966). Wien: Bauliche Gestalt und Entwicklung seit der Mitte des 19. Jh.

Braudel, F. (1949). Akdeniz ve Akdeniz Dünyası - 1. cilt. Eren Yayıncilık.

Butlin, R. A. (1993). Historical Geography: Through the Gates of Space And Time. London: Edward Arnold.

Caniggia, G., \& Maffei, G. (2001). Interpreing Basic Building Architectural Composition and Building Typology. Alinea Editrice, Firenze, Italy.

Cataldi, G. (2003). From Muratori to Caniggia: The Origins and Development of the Italian School of Design Typology. Urban Morphology, 7(1), 19-34.

Conzen, M.R.G. (1959-1960). Alnwick, Northhumberland (A Study in Town-Plan Analysis). Institute of British Geographers Publication 27. London: George Philip.

Conzen, M. P. (2009). How Cities Internalize Their Former Urban Fringes: A Cross- Cultural Comparison. Urban Morphology, 13(1), 29.

Cömert, N. Z. (2013). Testing an Integrated Methodology for Urban Typo-morphological Analysis on Famagusta and Ludlow. Doktora Tezi, Doğu Akdeniz Üniversitesi.

Cultural Human Geography. (2019). Retrieved from http:// www.aag.org/cs/publications

Forty, A. (2000). Words And Buildings: A Vocabulary of Modern Architecture. Thames \& Hudson London.

Geisler, W. (1924). Die Deutsche Stadt: Eine Beitrag Zur Morphologie Der Kulturlandschaft, J. Engelhorns Nachf.

Göncüoğlu, S. F. (2011). Șehir ve Semt Tarihi Metodolojisi. Tarih Nasll Yazılır? (339-344).

Gu, K. (2010). Exploring The Fringe Belt Concept in Auckland: An Urban Morphological Idea and Planning Practice. New Zealand Geographer, 66(1), (44-60).

Gümüşçü, O. (2010). Tarihi Coğrafya. İstanbul: Yeditepe Yayınevi.

Hamshere, J. D. (1987). Data Sources in Historical Geography. Historical Geography: Progress and Prospect. Londra: Croom Helm.

Hassinger, H., 1916, Kunsthistorischer Atlas von Wien Österreichische Kunsttopographie, 15 Vienna.

Hillier, B., \& Hanson, J. (1998). Space Syntax as a Research Programme. Urban Morphology, 2(2), (108-110) 
Jonston, R. J. (1997). The Dictionary of Human Geography.

Kim, K.J. (2012). The Study of Urban Form in South Korea, Urban Morphology, 16(2).

Krier, R. (1979). Typological and Morphological Elements of the Concept of Urban Space, Architectural Design.

Kropf, K. (2009). Aspects of Urban Form, Urban Morphology, 13 (59-63).

Larkham, P.J. (1998). Urban morphology and typology in the United Kingdom. Petruccioli A (ed) Typological Process and Design Theory. Aga Khan Program for Islamic Architecture, Cambridge, (159-178).

Levy, A. (1997). The typomorphological approach of G. Canniggia and his school thought. Urban Morphology, 1, 52-56.

Maretto, M. (2013). Saverio Muratori: Towards A Morphological School of Urban Design, Urban Morphology 17.2, 93-106.

Martiny, R. (1928). Die Grundrissgestaltung der Deutschen Siedlungen, J. Perthes.

Marzot, N. (2002). The Study of Urban Form in Italy. Urban Morphology, 6 (2), (59-73).

Mitchell, J. B. (1975). Historical Geography. London, English Universities Press.

Moudon, A. V. (1994). Getting To Know the Built Landscape: Typomorphology, Franck K.A. and Schneekloth, L., Ordering Space: Types in Architecture and Design, Van Nostrand Reinhold, New York, (289-311).

Moudon, A. V. (1997). Urban Morphology as an Emerging Interdisciplinary Field. Urban Morphology, 1), (3-10).

Muratori, S. (1959). Studi Per Una Operante Storia Urbana di Venezia. Rome: Instituto Poligraphico dello Stato.

Oliveira V, Monteiro C, Partanen J (2015) A Comparative Study of Urban Form. Urban Morphology, 19 (73-92).

Oliveira, V., (2019). J.W.R. Whitehand and the Historico-geographical Approach to Urban Morphology, Springer, https://doi. org/10.1007/978-3-030-00620-4

Pacione, M. (1987). Historical Geography. Londra: Croom Helm.

Petruccioli, A. (1998). Exoteric, Polytheistic Fundamentalist Typology. Typological Process and Design Theory (9-16). Aga Khan Program for Islamic Architecture at Harvard University and MIT, Cambridge U.S.

Pevsner, N. (1976). A History of Buildings Types. Washington DC 1976.

Rossi, A. (1982). The Architecture of the City. Opposition Books. The MIT Press. https://doi. org/10.1037/022444

Schlüter, O. (1899) Über den Grundriss der Städte. Zeitschrift der Gesellschaft für Erdkunde zu Berlin, 34 (446-462).

Slater TR (ed) (1990) The built form of western cities: essays for MRG Conzen on the occasion of his eightieth birthday. Leicester University Press, Leicester.

Slater, T. R. (2009). Historical Urban Morphologies. In R. Kitchin \& R. Thrift (Eds.), International Encyclopedia of Human Geography (59-65). UK: Elsevier.

Tekeli, İ. (2010). Birlikte Yazılan ve Öğrenilen Bir Tarihe Doğru. Tarih Vakfı Yurt Yayınları.
Tezer, S.T. (2019) Yerleșme Tarihi Analizinde Bir Cerçeve: Antakya Örneği. Doktora Tezi. Mimar Sinan Güzel Sanatlar Üniversitesi Șehir ve Bölge Planlama Bölümü.

Ünlü, T., \& Baş, Y. (2015). Mersin'de Morfolojik Süreçlerin Değerlendirilmesi. Y. Baş \& S. Barut (Edt.), Türkiye Kentsel Morfoloji Sempozyumu: Temel Yaklaşımlar ve Teknikleri - Bildiriler Kitabı. Mersin: Mersin Üniversitesi Yayınları.

Ünlü, Tolga. (2019). Mekânın Biçimlendirilmesi ve Kentsel Morfoloji. Y. Baş \& S. Barut (Edt.), Türkiye Kentsel Morfoloji Sempozyumu: Temel Yaklaşımlar ve Teknikleri - Bildiriler Kitabı. Mersin: Mersin Üniversitesi Yayınları. (59-70).

Whitehand, J.W.R. (1977). The Basis for an HistoricoGeographical Theory of Urban Form. Trans Inst Br Geogr NS 2 (400-416).

Whitehand, J.W.R. (1981). Background to the Urban Morphogenetic Tradition, J.W.R. Whitehand (Ed.), The Urban Landscape: Historical Development and Management, Institute of British Geographers Special Publication, 13 Academic Press, London, (1-24).

Whitehand, J. W. R. (1987). The Changing Face Of Cities: A Study of Development Cycles and Urban Form. Basil Blackwell, Oxford.

Whitehand, J. W. R. (1988) Urban fringe belts: development of an idea, Planning Perspectives 3, (48-58).

Whitehand, J. W. R. (2007). Conzenian Urban Morphology and Urban Landscapes. 6th International Space Syntax Symposium, ii-1-ii-9. http://www.spacesyntaxistanbul.itu.edu.tr/papers/invitedpapers/ Jeremy_whitehand.pdf

Whitehand J.W.R., Gu K, Conzen MP, Whitehand S (2014) The Typological Process and the Morphological Period: A Cross-Cultural Assessment. Environ Plan B Plan Des, 41, (512-533). 